\title{
Multi-scale Features of Baiu, the Summer Monsoon over Japan and the East Asia
}

\author{
By Kozo Ninomiya \\ Marine Department, Japan Meteorological Agency, Tokyo 100, Japan \\ and \\ Takako Akiyama \\ Meteorological Research Institute, Tsukuba, Ibaraki 305, Japan \\ (Manuscript received 29 June 1991, in revised form 13 November 1991)
}

\begin{abstract}
This review paper summarizes the authors' recent studies on the Baiu, the summer monsoon, over the Japan Islands and the adjacent areas.

The most important feature of the Baiu is the formation of the Baiu front, which is a long quasistationary precipitation belt extending from the southeastern foot of the Tibetan Plateau to Japan and further to the northwestern Pacific. The cold Baiu trough, the polar front and the Pacific subtropical anticyclone are the major large-scale circulation systems which have influence on the Baiu front. The frontogenesis and the generation of convective instability in the southwesterly flows along the westnorthwest periphery of the Pacific subtropical anticyclone are the primary factors for the formation of the Baiu front.

The structure of the Baiu front and the associated Baiu low-level jet stream, and the water vapor budget during the peak Baiu period are studied. The generation and release of the convective instability in the intense Baiu precipitation area are also analyzed.

The features of the meso- $\alpha$-scale disturbances in the Baiu frontal zone are studied by the spectral analysis of the relative vorticity field and the cloud amount. The meso- $\beta$ - and meso- $\gamma$-scale fine structures within the meso- $\alpha$-scale disturbances are demonstrated.

The most outstanding feature of the Baiu is that the motions of many scales (planetary, synoptic, meso- $\alpha$-, meso- $\beta$ - and meso- $\gamma$-scales) are interacting with each other. The multi-scale aspects of the Baiu are stressed in this review paper.
\end{abstract}

\section{Introduction}

The pre-summer monsoon rain season in the neighborhood of Japan is signified as the Baiu season. The rainy and moist weather in this season, and the various circulation systems which cause this rainy weather, as a whole, are recognized as the Baiu phenomena, or simply as the Baiu, in the present paper.

The Baiu season over Japan begins nearly simultaneously with the onset of the summer monsoon over central India. The Baiu onset coincides approximately with an abrupt shift of the subtropical jet stream from the south to the north of the Tibetan Plateau (Murakami, 1958). The duration of the Baiu season is about one and a half months from early June to mid July. Climatological aspects

(C)1992, Meteorological Society of Japan of the seasonal march of the Baiu were described by Yoshino (1965 and 1966). During the Baiu season, the rain belt, which is signified as the Baiu front, persists along the banks of the Yangtze River with its eastern edge passing through the Japan Islands. The Baiu front is associated with the lowlevel jet around $700 \mathrm{mb}$ (Murakami, 1958). Flohn and Oeckel (1956), Murakami (1959), Saito (1966), Kurashima (1968) and Asakura (1971) studied the moisture transport over the East Asia in Baiu season.

During 1968-1972 Baiu seasons, Baiu Rainstorms Project carried out the field experiment over the western Japan to study the Baiu front and rain producing systems in the Baiu front. Various studies were made utilizing the data obtained by the field experiment. Matsumoto et al. (1971) and Akiyama (1973b) described the features of the Baiu front 
and the associated low-level jet stream in detail. Matsumoto (1972, 1973) and Akiyama (1973a, c) pointed out the close relation between the intense rainfalls and the Baiu low-level jet stream. Akiyama (1973b, 1975), in the moisture budget studies for the intense rainfall period, showed that the vast amounts of water vapor are transported from the tropical western Pacific to the Baiu frontal zone by the low-level southerly and southwesterly flows.

Matsumoto et al. (1970), Akiyama (1973b), and Ninomiya and Akiyama (1971, 1972, 1973) showed that several small cyclones form as secondary members of a cyclone family on the Baiu front. They have a typical scale of $1000-3000 \mathrm{~km}$ and are termed as meso- $\alpha$-scale or medium-scale cyclones. They are the most important rain-producing systems in the Baiu front. When viewed at a particular instant in time, the Baiu front is made up of a number of meso$\alpha$-scale cyclones, separated by expanses of relatively small cloudiness. In other words, the Baiu front is regarded as the locus of a train of meso- $\alpha$-scale cyclones. Yoshizumi (1977) studied the structure of meso- $\alpha$-scale cyclones employing a composite technique and a harmonic analysis. Tokioka (1970, 1973) discussed, in theoretical studies, that these disturbances form only when an extremely small Richardson number is prescribed in the frontal zone.

It is an important finding that heavy rains are generally caused by a group of meso- $\beta$ - of meso- $\gamma$ scale disturbances embedded in a meso- $\alpha$-scale cyclone (Matsumoto and Akiyama, 1969). The behavior and structure of the meso- $\beta$ - and meso- $\gamma$-scale convective systems in the Baiu front have been studied for the various cases (Matsumoto and Akiyama, 1970; Matsumoto and Ninomiya, 1971; Ninomiya and Akiyama, 1974; Ninomiya and Yamazaki, 1979; Ninomiya et al., 1981; Akiyama, 1978, 1979).

Based on a hemispheric primitive equation model, Ninomiya (1980) showed that the moist and warm air advection by the low-level southeasterly flows is essential in generating convective instability and sustaining the convective activity in the Baiu front. By performing a series of numerical prediction experiments with and without the convective condensation process, Ninomiya and Tatsumi $(1980,1981)$ and Ninomiya et al. (1984) investigated the role of condensation heating on the development of meso- $\alpha$ scale disturbances and the maintenance of the Baiu front.

The aforementioned results of the studies up to 1984 were summarized in the review paper by Ninomiya and Murakami (1987).

Further studies on the Baiu front and associated disturbances have been made since 1984. Ninomiya and Muraki (1986) and Ninomiya (1989) studied the seasonal changes in the large-scale circulations over East Asia and the northwestern Pacific during the Baiu season of 1979. Ninomiya and Mizuno (1987) studied the variations of Baiu precipitation during 1951-1980 and discussed the large-scale characteristics of wet and dry Baiu.

The cloud images obtained by GMS (Geostationary Meteorological Satellite) indicate that meso- $\alpha$ scale cloud clusters develop frequently in association with the Baiu frontal disturbances. Akiyama (1984a, b), and Ninomiya et al. (1988a, b) studied a long-lived meso- $\alpha$-scale cloud cluster which passed along the Baiu front in 12-15 July 1979 by using GMS IR data. Akiyama (1989, 1990a and b) studied large- and meso- $\alpha$-scale variations of the Baiu front during July 1982 by the spectral analysis method.

The present review paper will summarize the results of the aforementioned studies. We will emphasize the characteristics of the Baiu front as a subtropical front and the multi-scale features of the Baiu front.

Although the large-scale features of the Baiu front change with the seasonal march, we will focus our attention on the features of the Baiu front and the Baiu frontal disturbances in the peak Baiu period over the Japan Islands and the adjacent areas.

\section{General description of the Baiu}

The monsoon is a name for the seasonal wind derived from Arabic mausim, a season. It was first applied to the seasonal winds over the Sea of Arabia, but it has been extended to similar winds in other parts of the world. We shall describe briefly the winter and summer monsoon over the East Asia.

The monthly mean sea-level pressure over the northern hemisphere in January 1990 is presented in the left panel of Fig. 1. The vast Siberian anticyclone centered over $\sim 45^{\circ} \mathrm{N} / 110^{\circ} \mathrm{E}$ and the strong Aleutian cyclone centered over $\sim 50^{\circ} \mathrm{N} / 180^{\circ}$ are the major circulation systems over East Asia and the northern Pacific in winter. The north-northeasterly winds prevail along the eastern-southeastern periphery of the Siberian anticyclone, and the northnorthwesterly winds prevail along the westernsouthwestern periphery of the Aleutian cyclone. These northerly winds, or winter monsoon, transport the cold dry continental airmass southward. Therefore the winter monsoon season is the dry season, in general, over East Asia. An airmass transformation takes place, when the cold dry continental airmass flows over the warm sea surface (Ninomiya, 1968, 1976; Ninomiya and Akiyama, 1976).

The monthly mean sea-level pressure in June 1990 is presented in the right panel of Fig. 1. The summer monsoon low over India and the Pacific subtropical anticyclone are the major circulation systems over East Asia and the northern Pacific in summer. The southerly winds prevail over East Asia. The southerly winds, or summer monsoon, transport the warm moist tropical airmass northward and cause a large amount of rainfall. The summer monsoon is, 

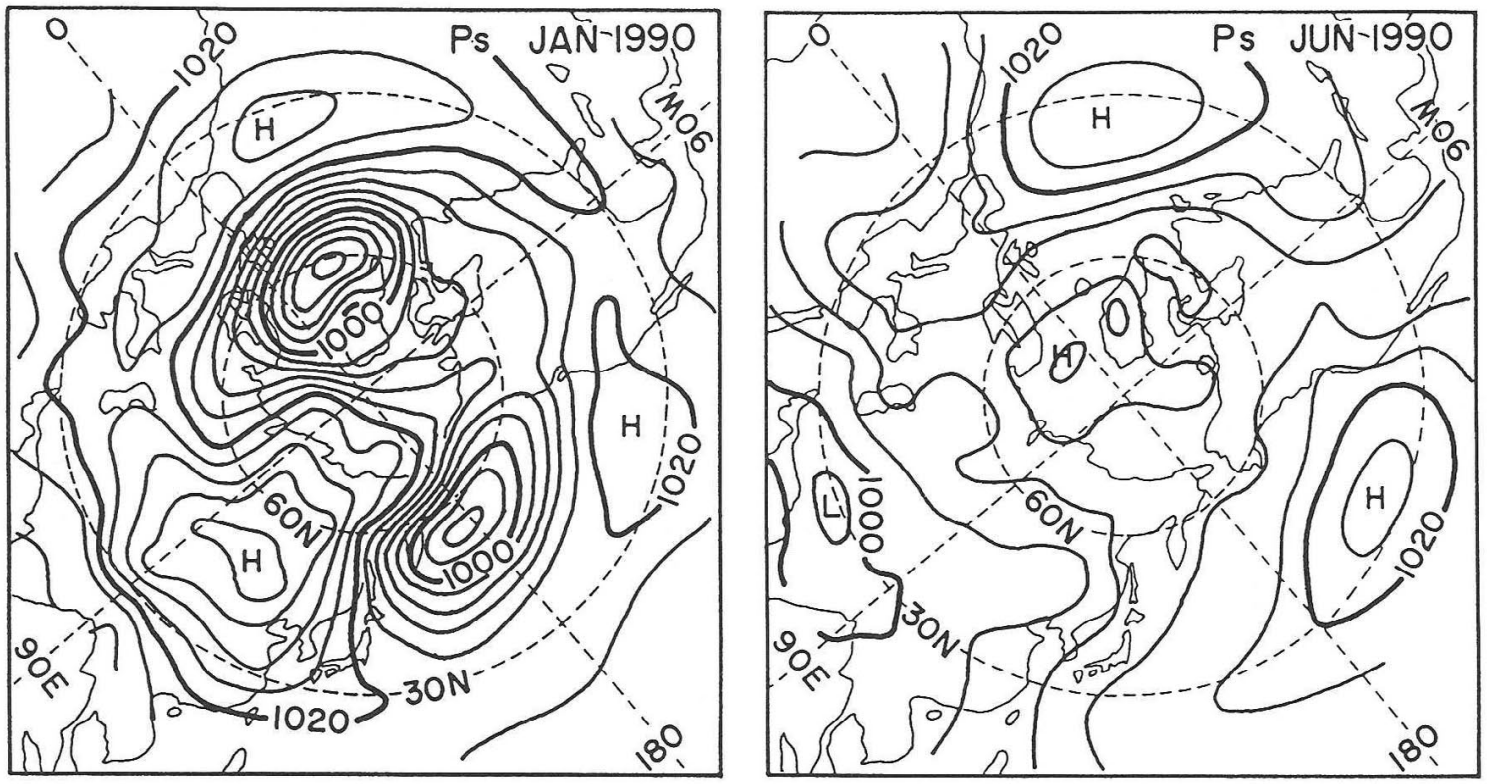

Fig. 1. The monthly mean sea-level pressure field over the northern hemisphere in January 1990 (left panel) and June 1990 (right panel). (Adapted from the mean maps in Monthly Report on Climate System for January 1990 and for June 1990, Japan Meteorological Agency.)

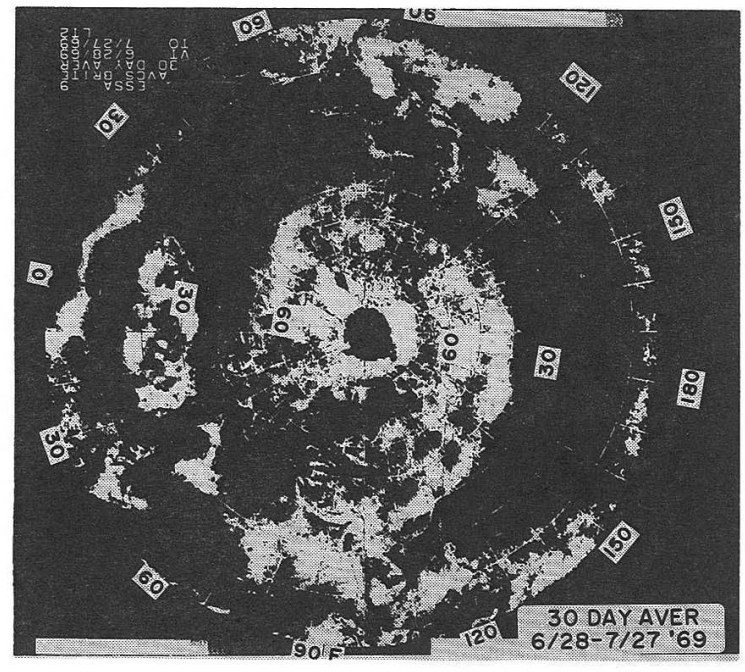

Fig. 2. The 30-day averaged ESSA-9 composite northern hemisphereric cloud brightness picture for 28 June-27 July 1969.

therefore, the rainy season of East Asia, which is called the "Baiu" season in Japan and the "Meiyu" season in China.

One of the important features seen in the Baiu season is a narrow cloud (precipitation) zone extending from the eastern foot of the Tibetan Plateau to the Japan Islands, and further to the northwestern Pacific. This cloud (precipitation) zone is called the Baiu frontal cloud (precipitation) zone, since it is associated with the quasi-stationary front which is called the Baiu front. Figure 2 is the 30-day averaged ESSA-9 composite northern hemispheric cloud

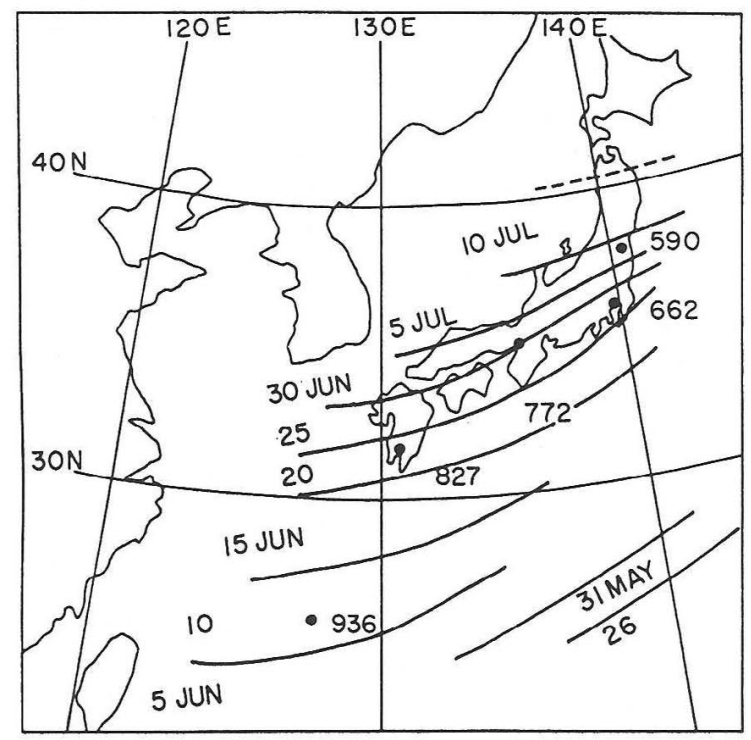

Fig. 3. Dates of maximum precipitation averaged for a 30-year period between 1951 and 1980 (Ninomiya and Murakami, 1987).

brightness picture for 28 June 27 July 1969. The long cloud zone extending from $\sim 25^{\circ} \mathrm{N} / 100^{\circ} \mathrm{E}$ to $\sim 45^{\circ} \mathrm{N} / 180^{\circ}$ is the Baiu frontal cloud zone. Climatologically speaking, the Baiu frontal cloud zone shifts gradually northward with the seasonal march, although the Baiu frontal cloud zone fluctuated north-south with a synoptic- and meso-scale time period (Akiyama, 1973b).

Figure 3 illustrates the dates of maximum precipitation (climatological value for the 30-year period of 1951-1980). The seasonal northward march 


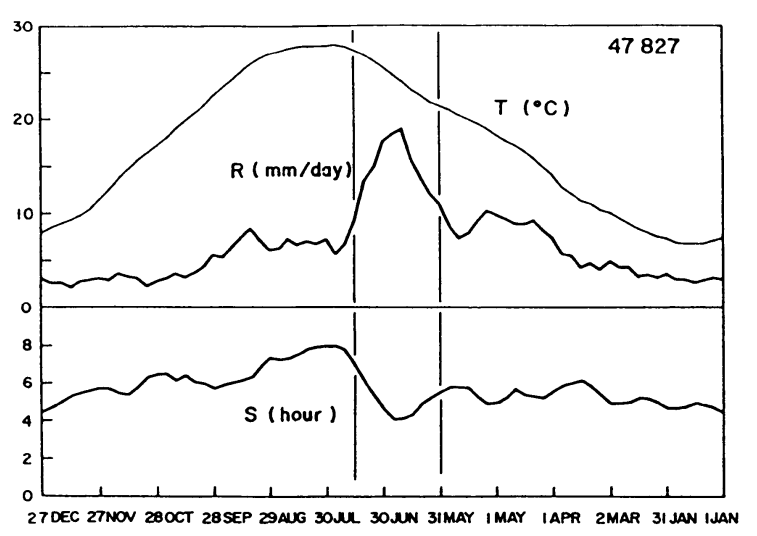

Fig. 4. Annual variation of temperature, precipitation, and sunshine duration at Kagoshima $\left(47-827 ; \sim 32^{\circ} \mathrm{N}, 130^{\circ} \mathrm{E}\right)$ averaged for the 30 -year period (Ninomiya and Mizuno, 1987).

of the rainy season (i.e., seasonal shift of the Baiu frontal zone) is seen. The rainfall peak over the southernmost parts of Japan occurs at the end of May or the beginning of June. The zone of peak precipitation shifts gradually northward. It reaches the southern coast of Japan on 25-30 June and the northern Japan on 10-15 July. The Baiu precipitation is largest ( $~ 800 \mathrm{~mm} /$ season at Kagoshima) over southwestern Japan. The precipitation peak is ill defined poleward of $\sim 40^{\circ} \mathrm{N}$. In general, the Baiu does not extend to the northernmost part of Japan north of about $40^{\circ} \mathrm{N}$.

Figure 4 shows the annual variation of air temperature, precipitation, and sunshine duration at Kagoshima $\left(47-827, \sim 32^{\circ} \mathrm{N} / 130^{\circ} \mathrm{E}\right)$ averaged for the 30 -year period. At Kagoshima, the Baiu season is evident as the period of peak precipitation and min- imum sunshine duration from 1 June to 15 July. The end of the Baiu is followed by high temperature and a sunshine duration maximum in midsummer.

The $850 \mathrm{mb}$ map at 12 GMT 9 July 1968 (Fig. 5) depicts a typical state at the peak of the Baiu period. A subtropical anticyclone extends from the Pacific $\left(\sim 30^{\circ} \mathrm{N}, 180^{\circ}\right)$ to the South China Sea $\left(\sim 15^{\circ} \mathrm{N}\right.$, $\left.115^{\circ} \mathrm{E}\right)$. The Baiu front forms along the northern rim of the Pacific subtropical anticyclone. There is a low-level strong WSW-ly wind $(15 \mathrm{~m} / \mathrm{sec}$ at 850 $\mathrm{mb}$ ) axis along the south side of the Baiu front in $100-135^{\circ} \mathrm{E}$. A large temperature difference exists between the Asiatic continent $\left(18-27^{\circ} \mathrm{C}\right)$ and the $\mathrm{Pa}-$ cific $\left(0-9^{\circ} \mathrm{C}\right)$ in $30-60^{\circ} \mathrm{N}$. The zone of strong thermal gradient relevant to the polar front is along $\sim 50^{\circ} \mathrm{N}$ over Siberia and along $\sim 40^{\circ} \mathrm{N}$ over the Pacific. The tip of the cold area (see the $15^{\circ} \mathrm{C}$ isotherm in Fig. 5) protrudes from the Bering Sea into the Japan Sea. The $850 \mathrm{mb}$ wind field indicates that the cold area is associated with a trough extending from the northwestern Pacific via the Japan Sea to $\sim 30^{\circ} \mathrm{N} / 110^{\circ} \mathrm{E}$. This trough is called the Baiu (Meiyu) trough (Chen and Chang, 1980; Saito, 1985: Ninomiya and Muraki, 1986).

One of the interesting features seen in Fig. 5 is a number of synoptic- and meso- $\alpha$-scale frontal depressions aligned along the Baiu front. These frontal depressions cause intense rainfalls within the Baiu front (Matsumoto et al., 1970: Ninomiya and Akiyama, 1971, 1972, 1973; Akiyama, 1978).

The top panel of Fig. 6 shows the daily precipitation at Kagoshima in June and July 1979. The peaks of precipitation occur with a few days' interval. These peaks are associated with the Baiu frontal depressions. The bottom panel in Fig. 6 shows the distribution of precipitation on 28 June 1979. The large amount of precipitation concen-

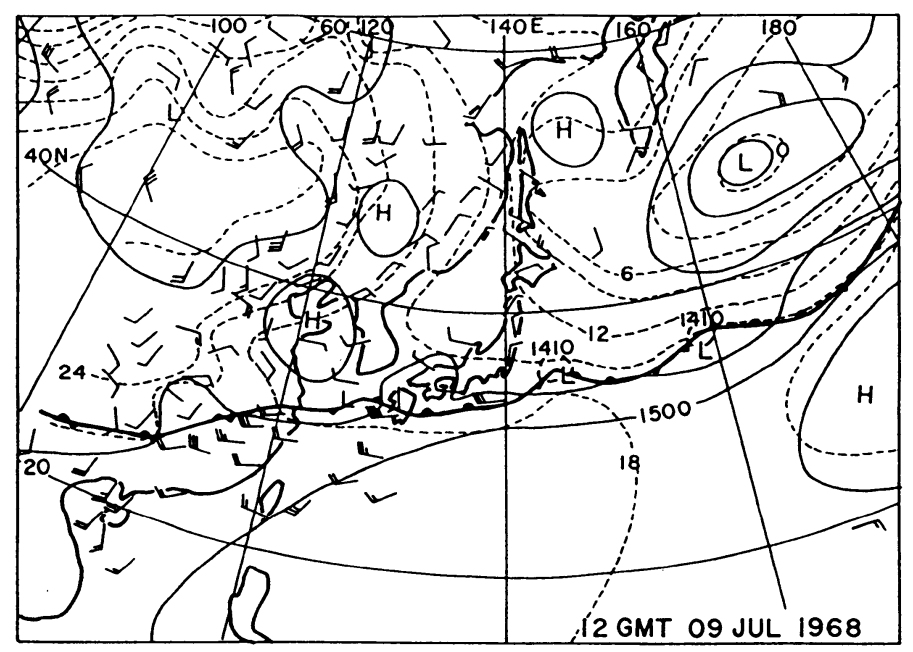

Fig. 5. The $850 \mathrm{mb}$ map of wind (a barb: $10 \mathrm{knot}$ ), temperature (dashed line) and geopotential height (full line) at 12 GMT 9 July 1968 (Ninomiya and Murakami, 1987). 

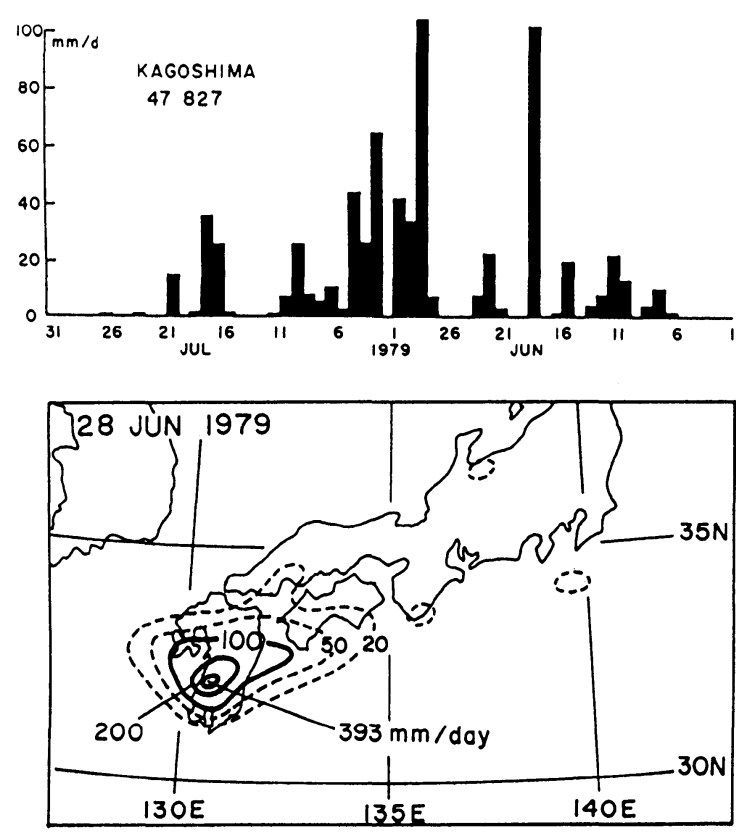

Fig. 6. Top: The daily precipitation at Kagoshima in June and July 1979. Bottom: Distribution of precipitation on 28 June 1979. (Ninomiya and Mizuno, 1987)

trates within the small area of $\sim(200 \mathrm{~km})^{2}$. The sporadic and localized nature of the Baiu precipitation is clearly depicted in Fig. 6.

The general description of the Baiu in this section shows that there are many viewpoints, from the planetary-scale to meso-scale, for studying the Baiu phenomena. In the following sections, we will discuss the Baiu from various viewpoints.

\section{Baiu front as a predominant subtropical front in the summer northern hemisphere}

The most important feature in the Baiu season is the formation of the Baiu front. From the planetaryscale viewpoint, the following problems will be discussed;

(1) Is the Baiu front a significant subtropical front?

(2) What is the main difference between the Baiu front and the polar front?

(3) What large-scale circulations work to sustain the Baiu front?

(4) Is there another subtropical front similar to the Baiu front in the northern summer hemisphere?

The present section will discuss the aforementioned problems by referring to Ninomiya (1984), who studied the large-scale features of the Baiu during 19-26 June 1975.

In order to avoid errors in estimating the vertical velocity and condensation rate from objective analysis data, the grid-point data of a 24-hour prediction by a hemispheric primitive equation model (6-layer in $\sigma$-system, $381 \mathrm{~km}$-mesh at $60^{\circ} \mathrm{N}$ ) were used in his analysis as the basic data. The data are obtained from 15 successive cases with a 12-hour interval for the period between 12 GMT 19 June (initial time 12 GMT 18) and 12 GMT 26 June 1975 (initial time 12 GMT 25). The analyses are made for these 15 successive cases. The primitive equation model used by Ninomiya (1984) is very simple and the resolution is poor as compared with recent models. However, we think that the results of his study still hold true, because the discussion was of planetary-scale features.

The top panel of Fig. 7 shows the distribution of precipitation averaged for the analysis period. Very intense precipitation occurs over the Indian monsoon area. Rainfalls of tropical storms are seen in low latitudes in the Pacific. A predominant precipitation zone extending along $30-35^{\circ} \mathrm{N}$ in $100-170^{\circ} \mathrm{E}$ corresponds to the Baiu front. The precipitation is especially heavy in $120-150^{\circ} \mathrm{E}$. Such a significant subtropical precipitation zone is not seen in other parts of the northern summer hemisphere. There are secondary precipitation zones in $45-70^{\circ} \mathrm{N}$ over North America, the Atlantic and Europe, which are related to the polar front.

The distribution of water vapor transport $1 / g \int_{300 \mathrm{mb}}^{p_{s}} \boldsymbol{V} q d p$ is presented in the bottom panel of Fig. 7. The southerly and the southwesterly moisture transports converge into the Baiu precipitation zone. The moisture transport around the rim of the Pacific subtropical anticyclone plays an important role in sustaining the large amount of precipitation within the Baiu frontal zone.

The top panel of Fig. 8 shows the potential temperature at $900 \mathrm{mb}$ averaged for the analyzed period $\left(\theta_{900}\right)$. The polar frontal zone appears as a zone of large $\nabla \theta_{900}$ along $\sim 60^{\circ} \mathrm{N}$. The gradient is very large $(\sim 10 \mathrm{~K} / 1000 \mathrm{~km})$ over North America, the northern Atlantic the northwestern Europe. The fairly large gradient of $\sim 5 \mathrm{~K} / 1000 \mathrm{~km}$ is seen along the southern boundary of the polar maritime airmass covering the northern Pacific. Over $30-60^{\circ} \mathrm{N}$ areas of the eastern Parts of the Asian Continent $\left(100-135^{\circ} \mathrm{E}\right), \theta_{900}$ is very high $(295-305 \mathrm{~K})$ and $\nabla \theta_{900}$ is very small. The Baiu frontal zone is not associated with the strong thermal gradient in the lower troposphere.

A cold trough extends from the polar marine airmass near the Kamchatka Peninsula to the Japan Sea and further to the Yellow Sea. This cold trough is usually recognized as the Baiu trough (see Section 4).

The bottom panel of Fig. 8 presents the specific humidity at $900 \mathrm{mb}\left(q_{900}\right)$. The $q_{900}$ is very large over the Asian tropical and subtropical areas. An especially large $q_{900}(\sim 15 \mathrm{~g} / \mathrm{kg})$ is seen to the south and southwest of the Baiu frontal zone. The eastward intrusion of the moist air along a $\sim 30^{\circ} \mathrm{N}$ latitude circle in the shape of a moist tongue is a characteristic of the Baiu front. The Baiu frontal zone is characterized by the large $\nabla q_{900}$ of $\sim 3(\mathrm{~g} / \mathrm{kg}) / 500$ 

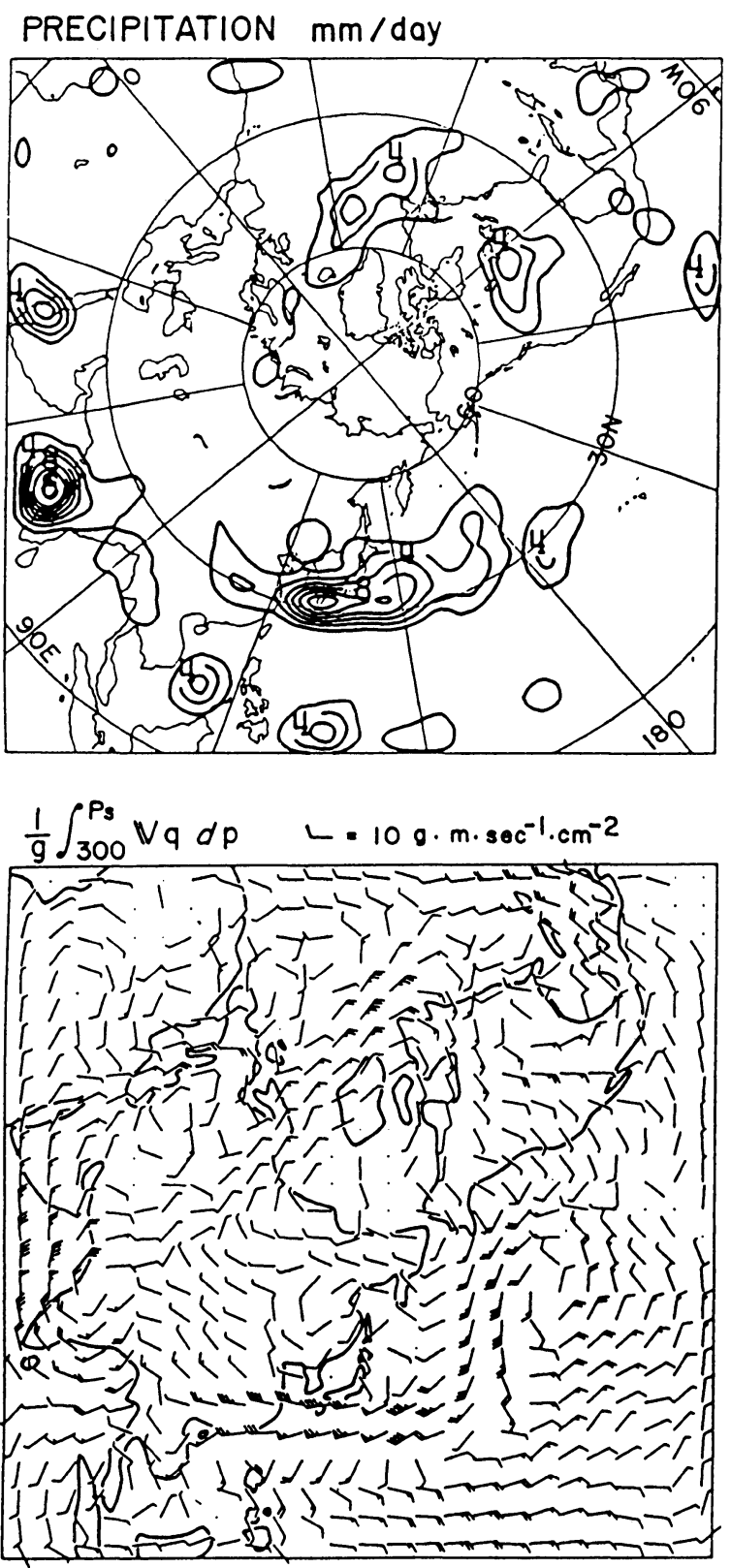

Fig. 7. Distribution of precipitation averaged for the analyzed period (units in $\mathrm{mm} /$ day, top panel) and the water vapor transport $1 / g \int_{300 \mathrm{mb}}^{p_{s}} V q d p$ (bottom panel). (Ninomiya, 1984)

$\mathrm{km}$, rather than the thermal gradient.

In general, the frontal zone corresponds to the zone of frequent passage of disturbances. In this period, the activity of disturbances is measured by the standard deviation of relative vorticity $(S . D . \zeta)$, which is obtained at each grid point by

$$
S . D . \zeta=\sqrt{1 / N \sum_{n=1}^{N}(\zeta-\bar{\zeta})^{2}}
$$

where $n, N(=15)$ and the bar notation $\left(^{-}\right)$indicate
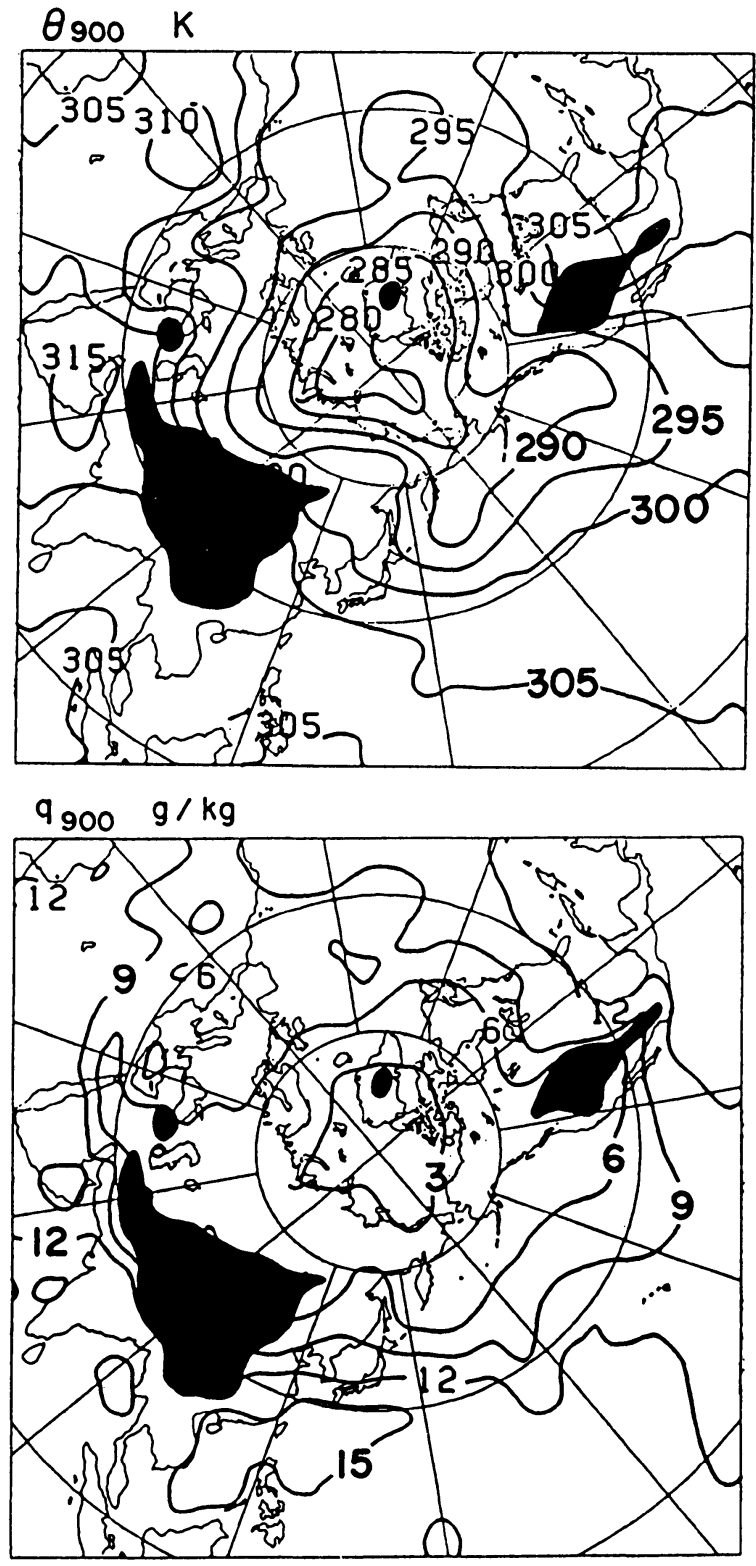

Fig. 8. Distribution of potential temperature (top panel) and specific humidity (bottom panel) at $900 \mathrm{mb}$ (Ninomiya, 1984).

successive cases, total number of the cases and the average for all cases, respectively. The distributions of $S . D . \zeta$ at $500 \mathrm{mb}\left(S . D . \zeta_{500}\right)$ and at $900 \mathrm{mb}$ $\left(S . D . \zeta_{900}\right)$ are presented in the top and the bottom panels of Fig. 9, respectively. The zone of large $S . D . \zeta_{500}$ is seen along $\sim 50^{\circ} \mathrm{N}$, which corresponds to the polar frontal zone. There are two zones of large S.D. $\zeta_{900}$. The one which corresponds to the polar front is seen in the $50-60^{\circ} \mathrm{N}$ zone over North America, the Atlantic and northwestern Europe. Another zone of large S.D. $\zeta_{900}$ extends along the northern side of the Baiu frontal precipitation zone. By comparing the distributions of S.D. $\zeta_{500}$ and S.D. $\zeta_{900}$, we note that the Baiu frontal disturbances are char- 

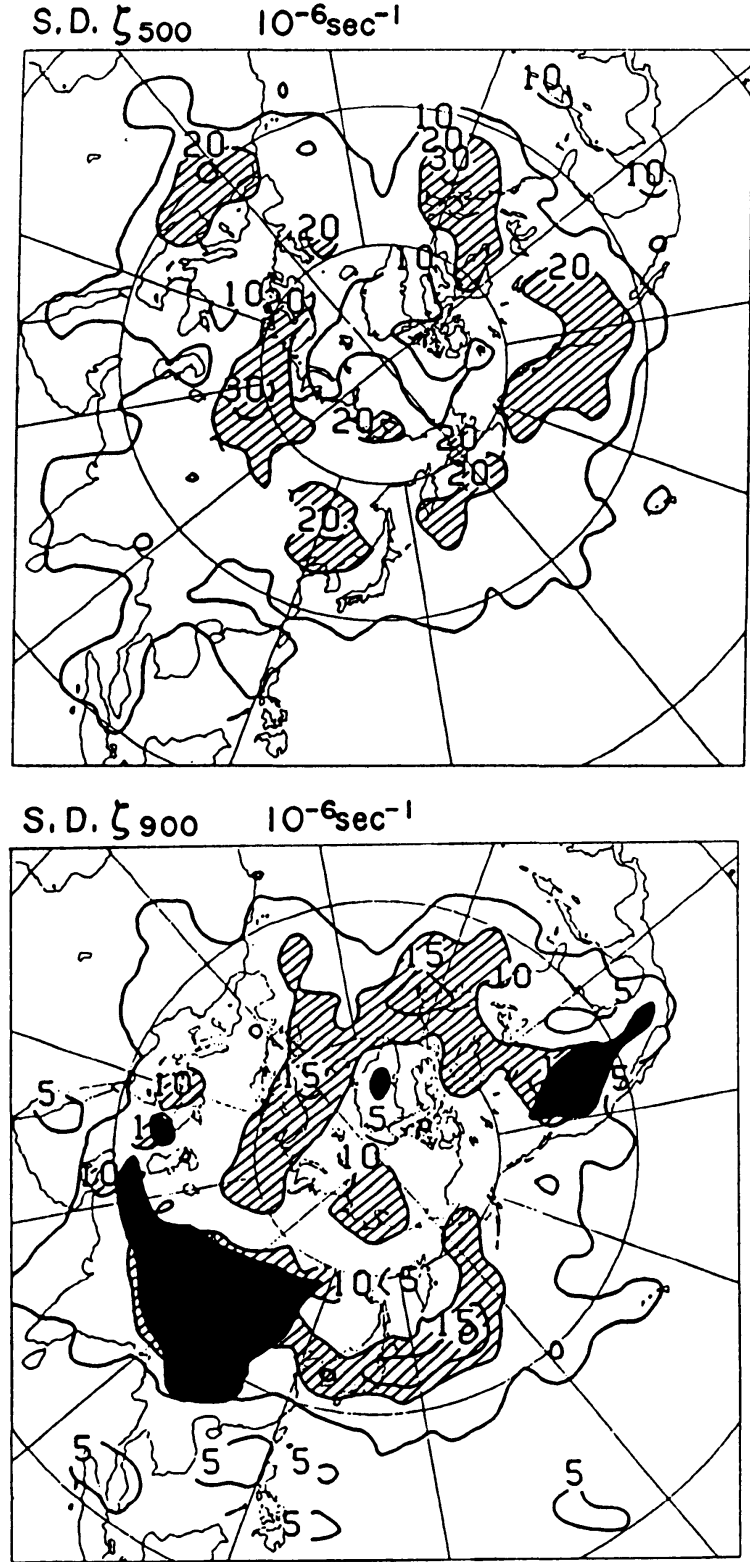

Fig. 9. Distribution of the standard deviation of 500 and $900 \mathrm{mb}$ vorticity (Ninomiya, 1984).

acterized by a large amplitude in the lower troposphere.

The top panel of Fig. 10 shows the equivalent potential temperature at $700 \mathrm{mb}\left(\theta e_{700}\right)$. The zone of large $\nabla \theta e_{700}$ in $50-60^{\circ} \mathrm{N}$ over North America, the Atlantic and northwestern Europe indicates the polar frontal zone. The area of very high $\theta e_{700}$ (340-350K) covers India, the Indo-China Peninsula, south China and the South China Sea. The zone of very large $\nabla \theta e_{700}(\sim 10 \mathrm{~K} / 300 \mathrm{~km})$ elongated from the eastern foot of the Tibetan Plateau corresponds to the Baiu front.

The $700 \mathrm{mb}$ wind field is presented in the bottom panel of Fig. 10. The southerly flows from the sub-
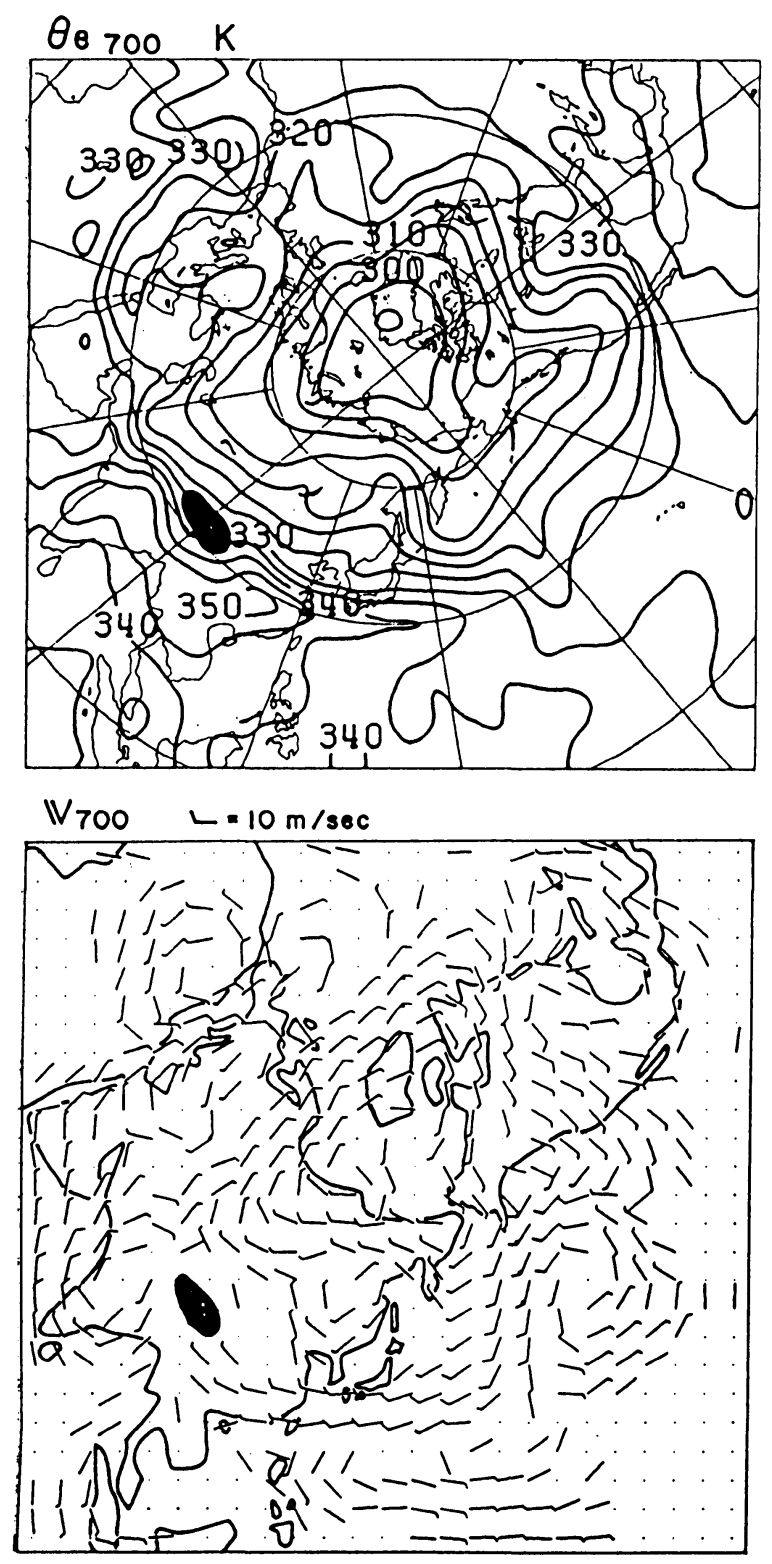

Fig. 10. Distribution of $700 \mathrm{mb}$ equivalent potential temperature $\theta e_{700}$ and $700 \mathrm{mb}$ wind velocity $V_{700}$ (Ninomiya, 1984).

tropical areas of East Asia and the western Pacific are confluent with the westerly flows in $30-40^{\circ} \mathrm{N}$. The fields of $\theta e_{700}$ and $\boldsymbol{V}_{700}$ indicate that the strong $\nabla \theta e_{700}$ is due to deformations. The frontogenesis term in the $\theta e$ field due to the deformation is evaluated by

FG3

$$
\begin{aligned}
& =\frac{1}{2} \frac{1}{|\nabla \theta e|}\left[\left\{\left(\frac{\partial \theta e}{\partial x}\right)^{2}-\left(\frac{\partial \theta e}{\partial y}\right)^{2}\right\}\left(\frac{\partial u}{\partial x}-\frac{\partial v}{\partial y}\right)\right. \\
& \left.+2 \frac{\partial \theta e}{\partial x} \cdot \frac{\partial \theta e}{\partial y}\left(\frac{\partial v}{\partial x}+\frac{\partial u}{\partial y}\right)\right] .
\end{aligned}
$$

The thus obtained $F G 3$ at $700 \mathrm{mb}$ is presented in 


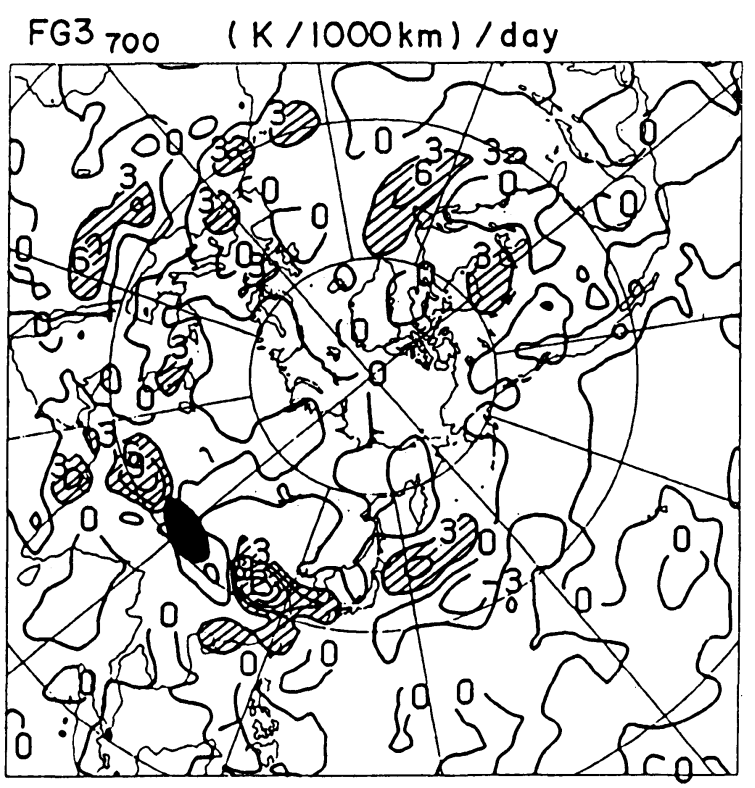

Fig. 11. Frontogenesis in $\theta e$ field due to deformation at $700 \mathrm{mb}$ (Ninomiya, 1984).

Fig. 11. The zone of large $F G 3$ extends into the Baiu frontal zone.

The precipitation in the Baiu front shows a convective nature (Section 2). We shall analyze the convective instability in/around the Baiu front. The top panel of Fig. 12 shows the distribution of convective instability $-\partial \theta e / \partial p$ in the $900-500 \mathrm{mb}$ layer. In general, the areas north to $30^{\circ} \mathrm{N}$ are covered by a convectively stable airmass, while the Indian monsoon region and the tropical-subtropical Pacific are characterized by a convectively unstable airmass. The Baiu frontal zone is characterized by an almost neutral or weak convectively unstable condition. This means that there is vertical convective mixing of $\theta e$ by the active convections in the precipitation zone.

The generation of convective instability due to the advection process is to be analyzed next. The time change of $\theta e$ by the advection of $\theta e$ is expressed by

$$
\left(\frac{\partial \theta e}{\partial t}\right)_{A D V}=-\left[\boldsymbol{V} \nabla \theta e+\omega \frac{\partial \theta e}{\partial p}\right] .
$$

The time change of convective instability by the differential advection is, therefore, expressed by

$$
\frac{\partial}{\partial t}\left(-\frac{\partial \theta e}{\partial p}\right)_{A D V}=\frac{\partial}{\partial p}\left[\boldsymbol{V} \nabla \theta e+\omega \frac{\partial \theta e}{\partial p}\right] .
$$

In the lower troposphere $(700 \mathrm{mb})$, a zone of very large $(\partial \theta e / \partial t)_{A D V}$ of $\sim 3 \mathrm{~K} /$ day is seen within the Baiu frontal zone (figure is not shown), which is due to the high $\theta e$ advection by the southwesterly winds. During this period, a large-scale cut-off low in the upper troposphere was resided near $\sim 50^{\circ} \mathrm{N} / 130^{\circ} \mathrm{E}$.
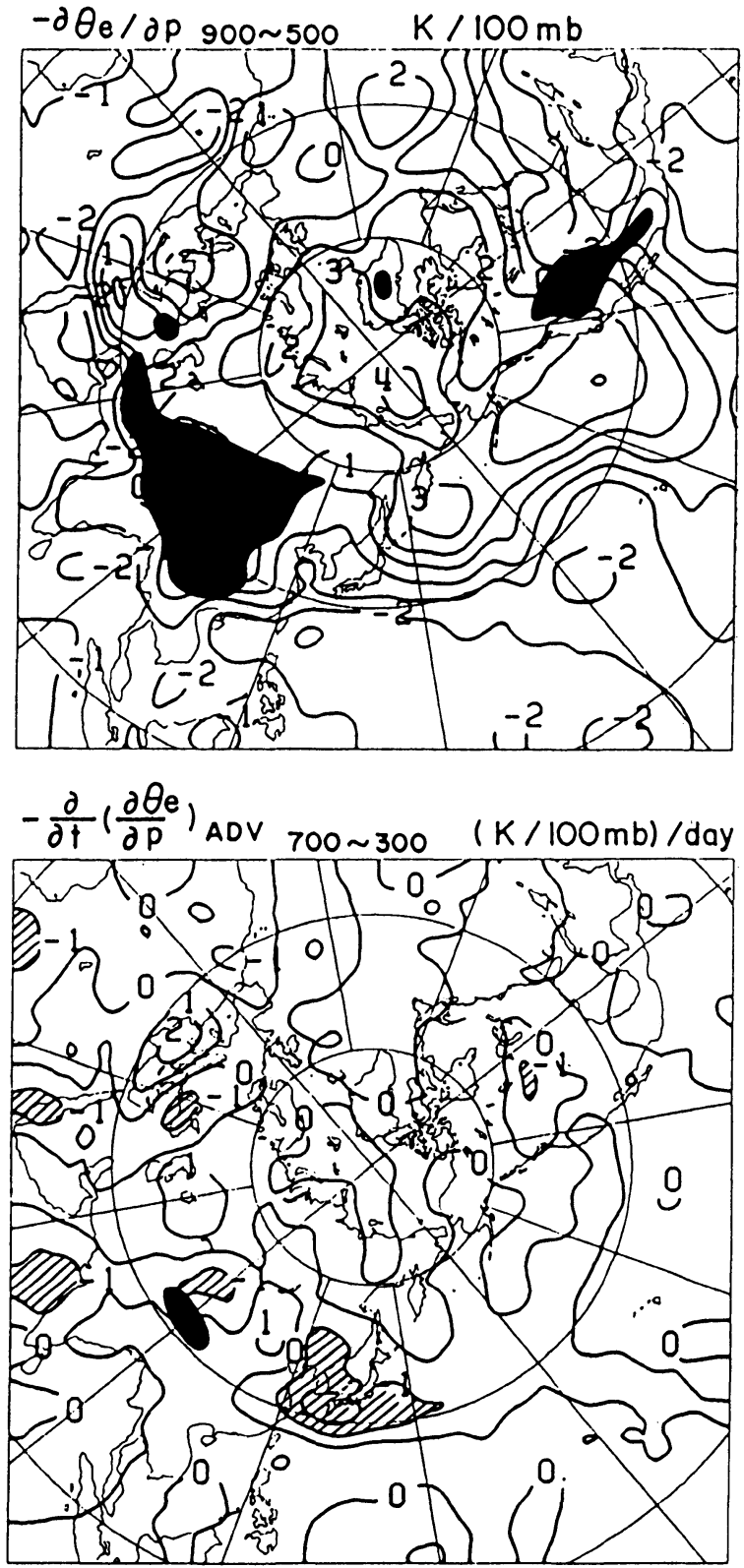

Fig. 12. Top panel: Distribution of convective instability $-\partial \theta e / \partial p$ in the $900-500 \mathrm{mb}$ layer. Bottom panel: Time change of convective instability due to the differential advection in the 700-300 mb layer. (Ninomiya, 1984)

At the $300 \mathrm{mb}$ level, there is an area of negative $(\partial \theta e / \partial t)_{A D V}$ of $\sim-4 \mathrm{~K} /$ day over the Japan Islands (a figure is not shown), which is due to the low $\theta e$ advection by the WNW-ly winds in the southwestern quadrant of the cut-off low. As a result, convective instability is generated in the Baiu frontal zone. The bottom panel of Fig. 12 shows the distribution of $\partial(-\partial \theta e / \partial p) / \partial t_{A D V}$ in the $700-300 \mathrm{mb}$ layer. There is a zone of convective instability generation in the Baiu frontal zone. The value of $\partial(-\partial \theta e / \partial p) / \partial t_{A D V}$ is $\sim-(2 \mathrm{~K} / 100 \mathrm{mb}) /$ day in this zone. Such an area of 
active generation of convective instability is not seen in other parts of the northern summer hemisphere. ${ }^{1}$

The results of the analysis in the present section will be summarized below: The polar frontal zone is defined as the zone of maximum $\nabla \theta$ located in 50 $60^{\circ} \mathrm{N}$. The Baiu frontal zone, which extends along a $\sim 30^{\circ} \mathrm{N}$ circle in $100-160^{\circ} \mathrm{E}$, is characterized by a narrow precipitation belt, strong gradients of specific humidity and equivalent potential temperature, a thick moist neutral layer, and the steady generation of convective instability. Because of this, the Baiu front is not a polar front, but a significant subtropical front of East Asia. Such a significant quasistationary subtropical front is not seen in other parts of the northern summer hemisphere.

The low-level southwesterly wind in the moist tropical airmass in the western periphery of the westward-protruding Pacific subtropical anticyclone is the primal condition for the formation of the Baiu front. The warm-moist advection due to the lowlevel southwesterly winds causes the frontogenesis, generation of convective instability and the strong moisture convergence.

\section{Large-scale circulation systems related to the Baiu front}

In Section 3, we stressed the role of the low-level SW-ly winds around the northwestern periphery of the Pacific subtropical anticyclone in sustaining the Baiu front. On the one hand, several studies (e.g., Chen and Chang, 1980; Lau and Li, 1984) showed the association of the Meiyu front with the Meiyu trough, which extends from the Japan Sea area to central China. Saito (1985) pointed out that the Baiu front is located to the southeast of a large-scale quasi-stationary $500 \mathrm{mb}$ trough, which extends from the north Pacific to central China.

Ninomiya and Muraki (1986) and Ninomiya (1989) made a comprehensive analysis of the largescale circulations over East Asia during the Baiu period of 1979. They paid attention to the large-scale circulation systems in both subtropical and high latitudes. In the present section, we will show some of the results of Ninomiya and Muraki (1986) briefly.

The top panel of Fig. 13 presents the $850 \mathrm{mb}$ geopotential height averaged for 10-day period between 21 and 30 June 1979. The amount of clouds whose top are higher than $400 \mathrm{mb}\left(C_{H}\right.$ : estimated from GMS IR observation) is also shown. The zone of maximum $C_{H}$ (Baiu frontal cloud zone) extends along the northwestern-northern periphery of the Pacific subtropical anticyclone.

\footnotetext{
${ }^{1}$ The upper level cold advection contributed significantly to the generation of convective instability in this mean field. In many cases of severe Baiu rainfall events, the contribution of the low-level warm-moist advection for the generation of convective instability is much larger than that of the upper level cold advection (Ninomiya, 1978; Akiyama, 1979; Ninomiya and Yamazaki, 1979; Ninomiya et al., 1984).
}
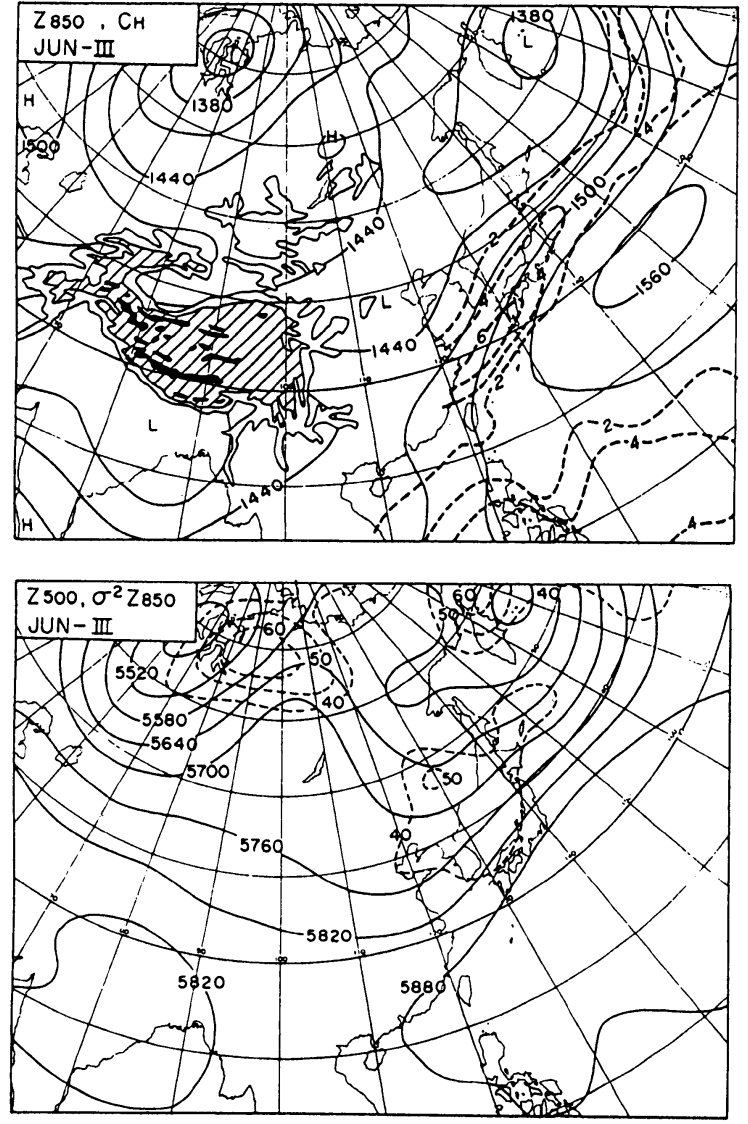

Fig. 13. Top panel: The 10-day averaged 850 $\mathrm{mb}$ geopotential height $\left(Z_{500}\right)$ and the high-cloud amount $\left(C_{H}\right.$ : estimated only over the sea areas, dashed lines) for 2130 June 1975. Contours of topography of 1500,3000 and $5000 \mathrm{~m}$ are shown in the map. Bottom panel: The 10-day averaged $500 \mathrm{mb}$ height $\left(Z_{500}\right)$ and the timevariance of $Z_{850}\left(\sigma^{2} Z_{850}\right.$, dashed lines) for 21-30 June 1979. (Ninomiya and Muraki, 1986).

On the $850 \mathrm{mb}$ map, a large-scale trough extends from the Bering Sea $\left(\sim 55^{\circ} \mathrm{N}, 165^{\circ} \mathrm{E}\right)$ to Sakhalin, and further to the eastern foot of the Tibetan Plateau $\left(\sim 37^{\circ} \mathrm{N}, 100^{\circ} \mathrm{E}\right)$. This is a typical feature of the Baiu trough. There is a ridge over the MongolSibirsk Plateaus extending from $\sim 70^{\circ} \mathrm{N} / 130^{\circ} \mathrm{E}$ to $\sim 40^{\circ} \mathrm{N} / 90^{\circ} \mathrm{E}$. This ridge is named the Baiu ridge in their paper.

The bottom panel of Fig. 13 shows the $500 \mathrm{mb}$ geopotential height averaged for the 10-day period. The Baiu trough and the Baiu ridge are also seen on the $500 \mathrm{mb}$ map. The time-variance of $850 \mathrm{mb}$ height during the 10-day period $\left(\sigma^{2} Z_{850}\right.$ : isolines are shown by dashed lines) is also shown. The large value of $\sigma^{2} Z_{850}$ seen to the southeast side of the 500 mb Baiu trough indicates development and passage of disturbances over this area. 


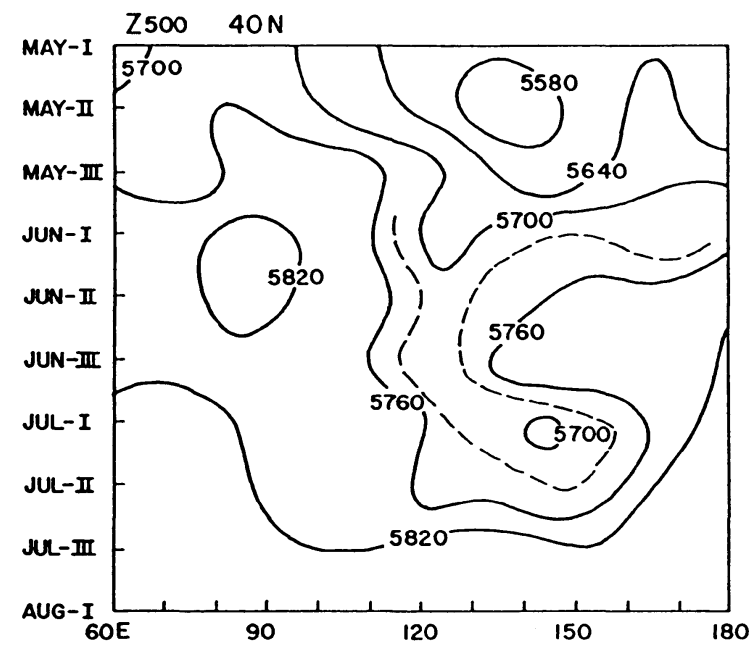

Fig. 14. The longitude-time section of the 10day-averaged $500 \mathrm{mb}$ height along $40^{\circ} \mathrm{N}$ circle (Ninomiya and Muraki, 1986).

The longitude-time section of the 10-day averaged $500 \mathrm{mb}$ height along a $40^{\circ} \mathrm{N}$ latitude circle is presented in Fig. 14. The Baiu trough and Baiu ridge begin to develop in late May. Although they fluctuate with a short time period, they are sustained through the Baiu season, and disappear around the end of July.

The Baiu front, which is characterized by a strong moisture gradient, forms also in late May (Ninomiya and Muraki, 1986). Kato (1985) noted that the formation of the Baiu front was associated with the abrupt decrease of the thermal gradient and increase of the convective instability over southern China.

The typical thermal field in the lower troposphere in the peak Baiu period of 1979 was seen at the beginning of July 1979. The $850 \mathrm{mb}$ thermal field averaged for the 10-day period between 1 and 10 July 1979 is presented in the top panel of Fig. 15. The Baiu ridge is characterized by a high temperature, and the Baiu trough by a low temperature. The 850 mb wind field for 21-30 June 1979 is shown in the bottom panel of Fig. 15. The northeasterly winds to the west side of the Baiu trough (hereafter abbreviated to Baiu trough Ne-ly winds) advect the cold air and thus maintain the low temperature within the Baiu trough. Over China $\left(\sim 35^{\circ} \mathrm{N}, 105-120^{\circ} \mathrm{E}\right)$, a distinct shear line forms between the Baiu trough NE-ly winds and the southerly wind from the South China Sea, which is named the Baiu (Meiyu) shear line in this section.

The schematic illustration of the large-scale circulations on the $850 \mathrm{mb}$ surface during the peak Baiu period is given in Fig. 16. The axes of the Baiu ridge, Baiu trough and the Baiu shear line are indicated. The axes of the Baiu trough NE-ly winds, Indian monsoon westerly winds, the South China Sea southerly winds, and SW-WSW-ly winds along
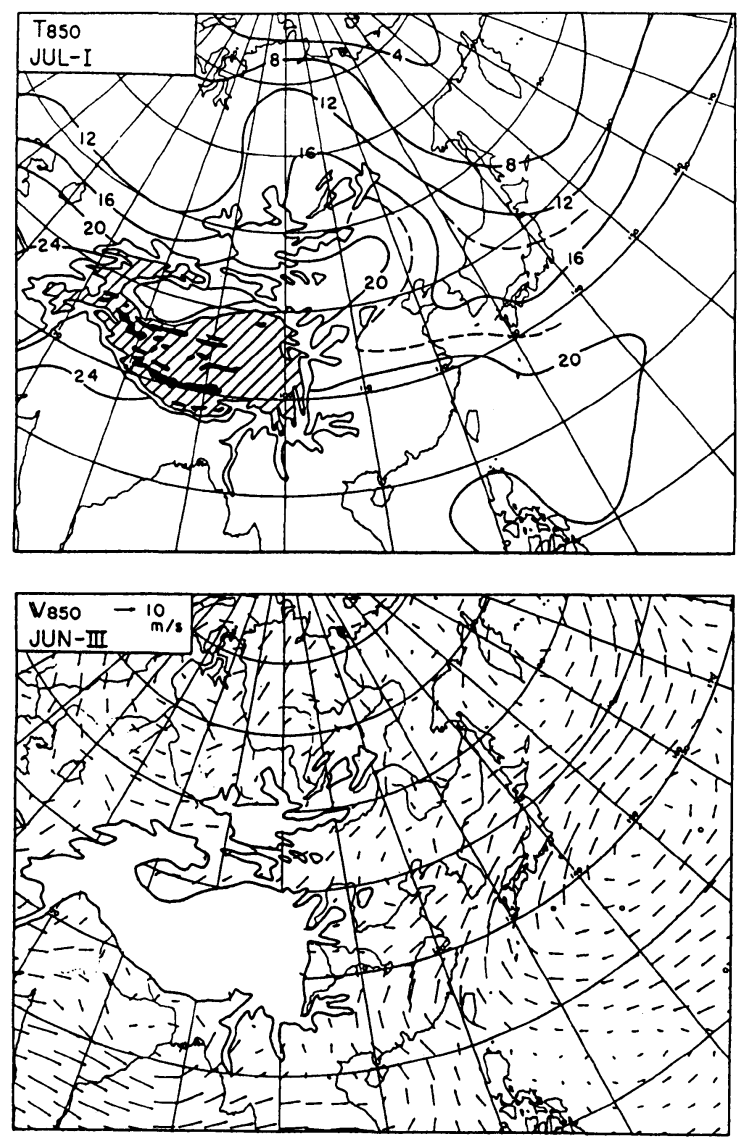

Fig. 15. Top panel: The 10-day-averaged 850 mb temperature $\left(T_{850}\right)$ for 1-10 July 1979. Bottom panel: The 10-day-averaged 850 $\mathrm{mb}$ wind velocity $\left(V_{850}\right)$ for 21-30 June 1979. (Ninomiya and Muraki, 1986).

the Pacific subtropical anticyclone are indicated schematically by arrows. Hatching over the sea areas represents areas of large high-cloud amount $\left(C_{H}>\right.$ $0.4)$, which corresponds to the Baiu front. Hatching over China indicated the regions of large precipitation of more than $100 \mathrm{~mm} / 10$-day, which corresponds to the Meiyu front (western part of the Baiu front).

In the Baiu period, the noteworthy features are the warm Baiu ridge over the Mongol-Sibirsk Plateau, the cold Baiu trough extending from the Bering Sea to China, and the westward-protruding Pacific subtropical anticyclone.

The important low-level circulations are the Baiu trough NE-ly winds, South China Sea southerly winds, the low-level-jet-like WSW-ly winds along the periphery of the Pacific subtropical anticyclone, and the monsoon westerly winds which extend eastward and turn to southerly winds over the South China Sea. The Tibetan Plateau and the Baiu trough NE-ly winds prevent the northward intrusion of the tropical airmass and sustain a strong moisture gradient along the Meiyu front. (i.e., the Baiu front 


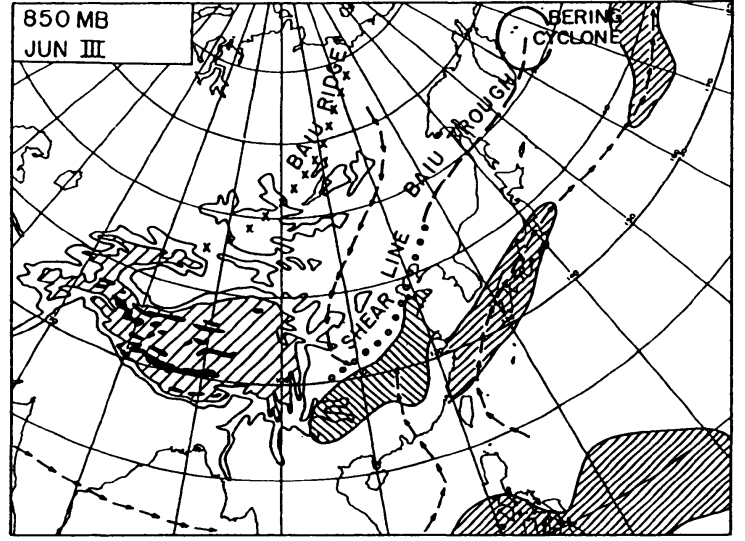

Fig. 16. The schematic illustration of the Baiu ridge, and Baiu trough, Baiu shear line at $850 \mathrm{mb}$. The axis of the Baiu trough NEly winds, Indian monsoon westerly winds, the South China Sea southerly winds and SW-WSW-ly winds along the periphery of the Pacific subtropical anticyclone at 850 $\mathrm{mb}$ are indiçated by arrows. Hatching over the Pacific indicates the zone of large $C_{H}$ (i.e., the Baiu frontal cloud zone). Hatching over China indicates the area of precipitation more than $100 \mathrm{~mm} / 10$-day (the precipitation map is reproduced from Luo and Yanai, 1983). (Ninomiya and Muraki, 1986).

over China). Over the Pacific, east of Japan, the northerly winds to the rear of the Bering cyclone prevent the northward shift of the Baiu front. The role of the Tibetan Plateau and the Bering cyclone in sustaining the Baiu front is also studied in the numerical experiments by Nakamura and Hasegawa (1987).

While the Meiyu front is related to the low-level convergence in the Baiu (Meiyu) shear line, the Baiu front forms along the northwestern-northern periphery of the Pacific subtropical anticyclone. The Baiu front around the Japan Islands is located about 1000 $\mathrm{km}$ south from the Baiu trough.

Similar features of the large-scale circulations in the Baiu season were also described by Kato (1989).

\section{The Baiu front in the peak Baiu period over southwestern Japan}

In the present section, we will discuss the features of the Baiu front in the peak Baiu period over southwestern Japan, where the precipitation is most intense. In this section, we use the original observational data, instead of the objective analysis data, to analyze the detailed features.

The distribution of $850 \mathrm{mb}$ wind velocity averaged for 1-5 July 1968 is presented in the top panel of Fig. 17. The thin stippling indicates the cloud zone where the cloud amount exceeds 0.4. The dense stippling shows the area where precipitation is greater than $50 \mathrm{~mm} / 5$-day. The low-level jet-like strong WSW-ly winds $(\sim 15 \mathrm{~m} / \mathrm{sec})$ are seen to the south of the Baiu front. These winds are called the Baiu low-level jet. ${ }^{2}$ Intense rainfall occurs along the north side of the Baiu low-level jet stream (Akiyama, 1973c). The low-level jet indicates a significant ageostrophic feature (Matsumoto et al., 1971; Akiyama, 1973a, b).

The low-level specific humidity is very large in the tropical airmass over the area south of the Baiu front. Owing to the high specific humidity and the strong winds of the low-level jet, very large moisture transport occurs to the south of the Baiu front. The bottom panel of Fig. 17 shows the distribution of moisture flux $1 / g \int_{500 \mathrm{mb}}^{p_{s}} \boldsymbol{V} q d p$ averaged for 1-5 July 1968. The inflow of moisture flux due to the southerly wind into the Baiu frontal zone is important for producing the precipitation within the Baiu front and also sustains the eastward transport of the moisture.

Figure 18 shows the vertical distribution of the $\mathrm{u}$ - and v-component of water vapor flux for area A (southern China), B (the East China Sea) and C (western Japan) during 1--5 July 1968. The dimensions and the location of these areas are shown in Table 1. The abscissa is the water vapor in- and out-flux for a layer of $1 \mathrm{mb}$ depth. The numerals denote the vertically integrated amount of in- and out-flux for the layer indicated in the diagram.

In these areas, the outgoing moisture flux across the eastern boundary is much larger than the influx across the western boundary. That is, there is large longitudinal flux divergence of water vapor $(\partial u q / \partial x$ is positive). This large longitudinal flux divergence and the precipitation in these areas are sustained by the large meridional convergence of the $\mathrm{v}$-component of water vapor flux ( $\partial v q / \partial y$ is negative), which is mainly due to a large influx in the lower layer across the southern boundary of these areas.

The $200 \mathrm{mb}$ jet-stream axis, the $300 \mathrm{mb}$ thermal and the $400 \mathrm{mb}$ specific humidity fields for 1-5 July 1968 are illustrated on the top panel of Fig. 19. The bottom panel of Fig. 19 shows the $850 \mathrm{mb}$ height and thermal field in the 5-day period. In the map, the zone of large cloud amount of more than 0.4 is indicated by hatching. The Baiu front forms along the periphery of the Pacific subtropical anticyclone. The northern boundary of the Baiu front is limited by the cold area of the Baiu trough at $850 \mathrm{mb}$.

In the middle troposphere, the moist zone extends

\footnotetext{
${ }^{2}$ Figure 17 shows the WSW-ly Baiu low-level jet stream over Japan in the time-averaged field. The southerly Baiu low-level jet stream appears over southern China (Fig. 16). The heavy Baiu rainfalls over Japan are also associated with a southerly or SWS-ly low-level jet stream (Akiyama, 1975; Ninomiya and Yamazaki, 1979).
} 

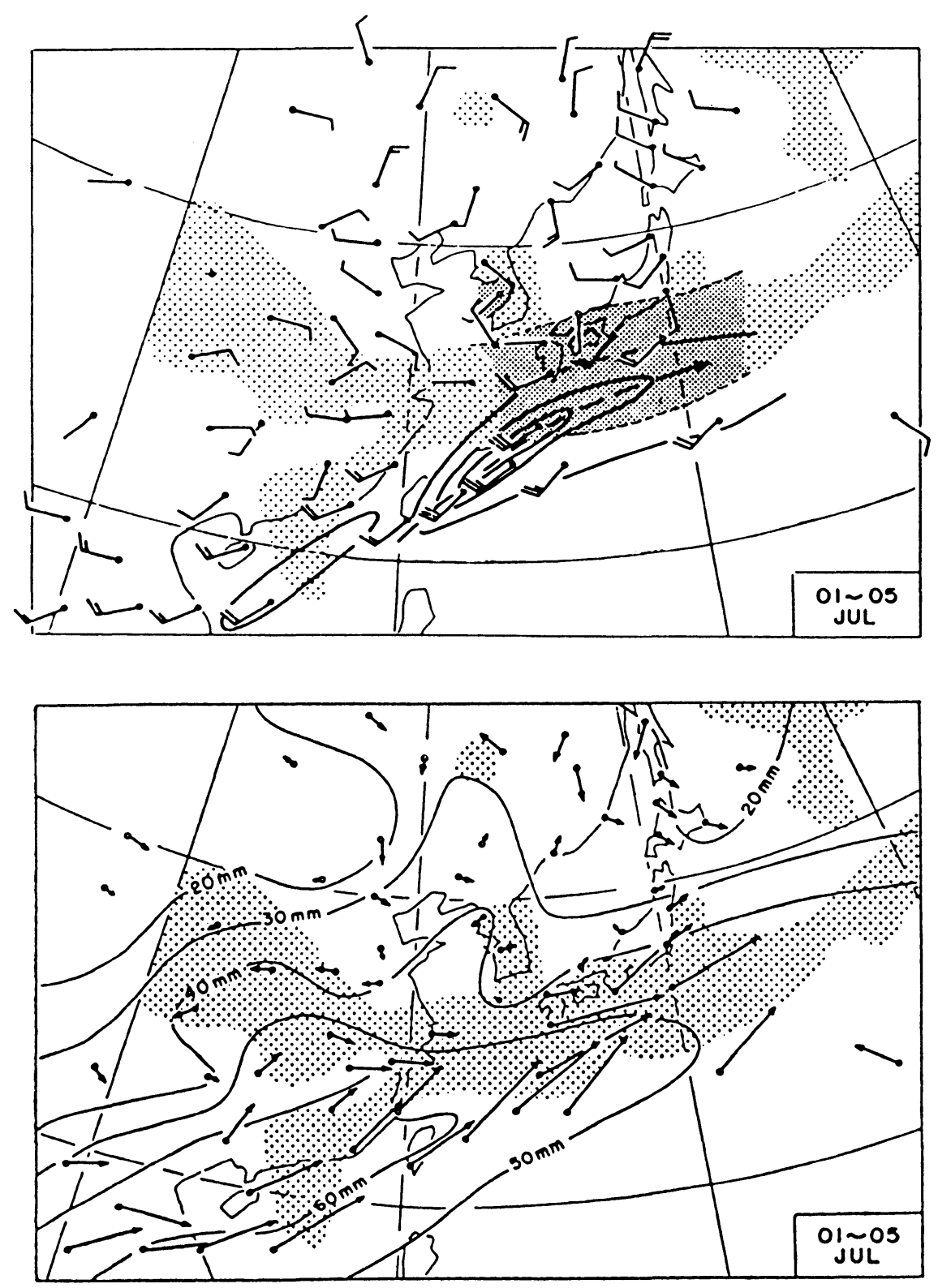

Fig. 17. Top panel: The $850 \mathrm{mb}$ wind velocity averaged for $1-5$ July 1968 . The thin stippling indicates the Baiu frontal cloud zone (cloud amount of more than 0.4) and the dense stippling indicates the area of precipitation of more than $50 \mathrm{~mm} / 5$-day. Bottom panel: The moisture flux $1 / g \int_{500 \mathrm{mb}}^{p_{s}} V q d p$ averaged for the 5-day period. An arrow with $18 \mathrm{~mm}$ length indicates the moisture flux of $60 \times \mathrm{gm} \cdot \mathrm{m} \cdot \mathrm{sec}^{-1} \cdot \mathrm{cm}^{-2}$. The thin lines show the isolines of precipitable water $\left(1 / g \int_{500 \mathrm{mb}}^{p_{s}} q d p\right)$. (Akiyama, 1973b).

from the intense precipitation area to eastward as the moist tongue. This indicates a vertical transport of moisture in the active Baiu front due to the upward motion of the frontal depressions and convections. The warm tongue at $300 \mathrm{mb}$ appears over the moist tongue in the middle troposphere. The condensation heating will contribute to forming the warm tongue in the upper troposphere. Consequently, the most strong thermal gradient in the middle-upper troposphere is seen along the north side of the warm tongue. Therefore, the $200 \mathrm{mb}$ jetstream axis runs along the north side of the Baiu precipitation zone. In many cases, the Baiu heavy rainfall zone is seen to the north of the low-level jet, and to the south of the high-level jet stream.

Figure 20 shows the vertical cross section along $130^{\circ} \mathrm{E}$ of the $\mathrm{u}$-component of wind velocity and the equivalent potential temperature, averaged for 3-10 July 1969. The axis of strong wind tilts northward with height. The core of the low-level jet stream in excess of $18 \mathrm{~m} / \mathrm{sec}$ is around $33^{\circ} \mathrm{N}$ at $700 \mathrm{mb}$, while $\mathrm{u}$ at $850 \mathrm{mb}$ is largest $(\sim 15 \mathrm{~m} / \mathrm{sec})$ around $30^{\circ} \mathrm{N}$. During this period, the time-averaged precipitation of $\sim 30 \mathrm{~mm} /$ day is observed in $31-33^{\circ} \mathrm{N}$. Very strong 

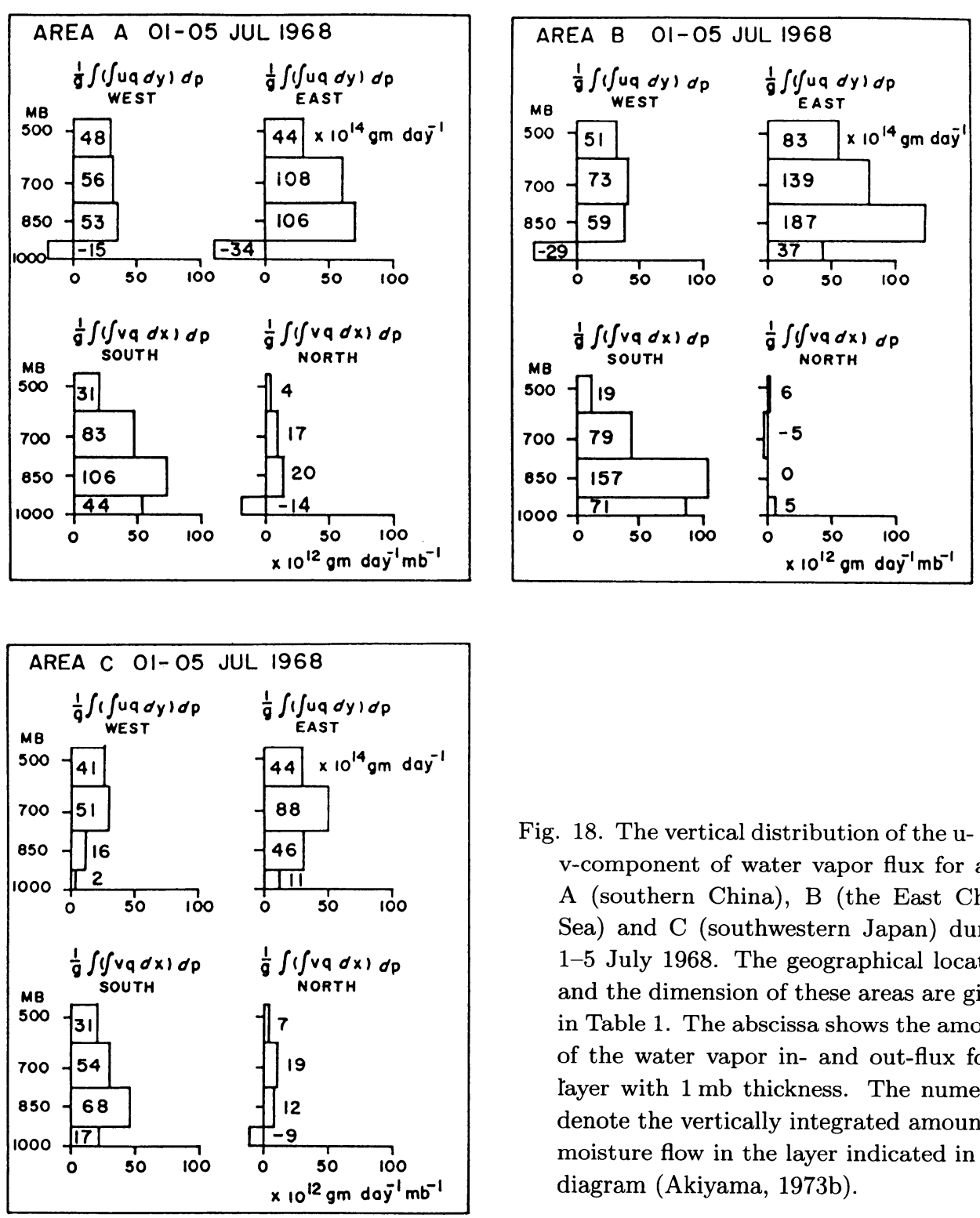

Fig. 18. The vertical distribution of the $u-$ and v-component of water vapor flux for area A (southern China), B (the East China Sea) and C (southwestern Japan) during 1-5 July 1968. The geographical location and the dimension of these areas are given in Table 1. The abscissa shows the amount of the water vapor in- and out-flux for a layer with $1 \mathrm{mb}$ thickness. The numerals denote the vertically integrated amount of moisture flow in the layer indicated in the diagram (Akiyama, 1973b).

Table 1. The geographical location and the dimension of areas A, B and C, where the water vapor budget is studied (see Fig. 18).

\begin{tabular}{llcc}
\hline & Geographical area & Center of area & Dimension \\
A & Southern China & $26^{\circ} \mathrm{N}, 115^{\circ} \mathrm{E}$ & $94.2 \times 10^{4} \mathrm{~km}^{2}$ \\
B & The East China Sea & $29^{\circ} \mathrm{N}, 125^{\circ} \mathrm{E}$ & $72.3 \times 10^{4} \mathrm{~km}^{2}$ \\
$\mathrm{C}$ & Southwestern Japan & $34^{\circ} \mathrm{N}, 135^{\circ} \mathrm{E}$ & $31.8 \times 10^{4} \mathrm{~km}^{2}$ \\
\hline
\end{tabular}

vertical shear of $u$ is found under the core of the lowlevel jet stream, while a large lateral shear is seen to the north of the core. The thermal gradient in the Baiu frontal zone around $130^{\circ} \mathrm{E}$ is weak. Thus, the vertical wind shear under the jet's core can not be fully accounted for by the thermal wind relation (Matsumoto et al., 1970, 1971; Matsumoto, 1973; Akiyama, 1973c).

Figure 20 shows a large meridional gradient of $\theta e$ poleward of $35^{\circ} \mathrm{N}$. This region is convectively stable. The lower troposphere to the south of the low-level jet core is convectively unstable in association with moist tropical air below the inversion layer and dry air of Pacific origin above the inversion. There is a thick moist neutral layer $(\theta e: 336-338 \mathrm{~K})$ within the zone of intense convective precipitation $\left(32-33^{\circ} \mathrm{N}\right)$.

In the middle and upper troposphere, $\theta e$ above the Baiu front is much higher than on the north and 

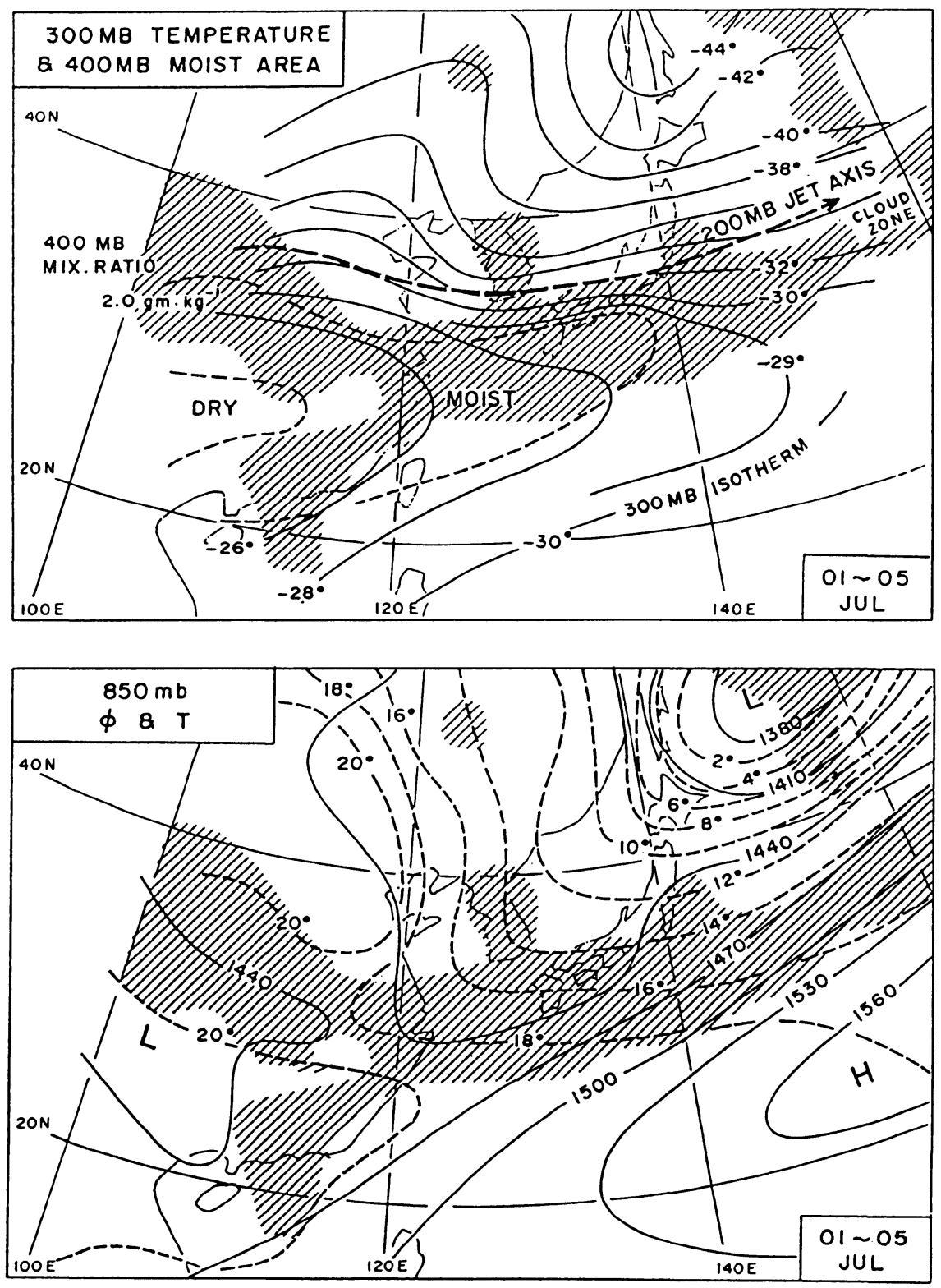

Fig. 19. Top panel: The location of the $200 \mathrm{mb}$ jet-stream axis, $300 \mathrm{mb}$ thermal field and $400 \mathrm{mb}$ specific humidity field during 1-5 July 1968. Bottom panel: The $850 \mathrm{mb}$ height and thermal field during 1-5 July 1968. The hatched area shows the Baiu frontal cloud zone. (Akiyama, 1973b).

south sides of the Baiu front. This corresponds to the moist, warm tongue described in Fig. 19.

Several authors have discussed the mechanisms of the vertical circulation around the Baiu low-level jet stream of ageostrophic nature and also the mechanisms of formation of the ageostrophic low-level jet stream in the Baiu front (Matsumoto, 1972, 1973). However, more detailed observations will be needed to reach a conclusive answer.

\section{An example of intense precipitation in the Baiu front}

Various case studies of Baiu front and the Baiu frontal disturbances associated with intense precip- itation have been studied in several papers (e.g., Matsumoto and Akiyama, 1969; 1970; Matsumoto and Ninomiya, 1971; Ninomiya, 1978; Ninomiya and Akiyama, 1971, 1972, 1973, 1974; Ninomiya and Yamazaki, 1979; Ninomiya et al., 1981, 1984, 1988a, b). Although the features of Baiu intense rainfalls varied from case to case, some common characteristics are found in the Baiu frontal heavy rainfall events. They are the formation of low-level SW-ly jet stream, generation of convective instability, and the organization of the mesoscale convective cloud system in the mesoscale convergence area. As an example of the Baiu frontal intense rainfall event, the case on 27 June 1972 is presented in this section. 

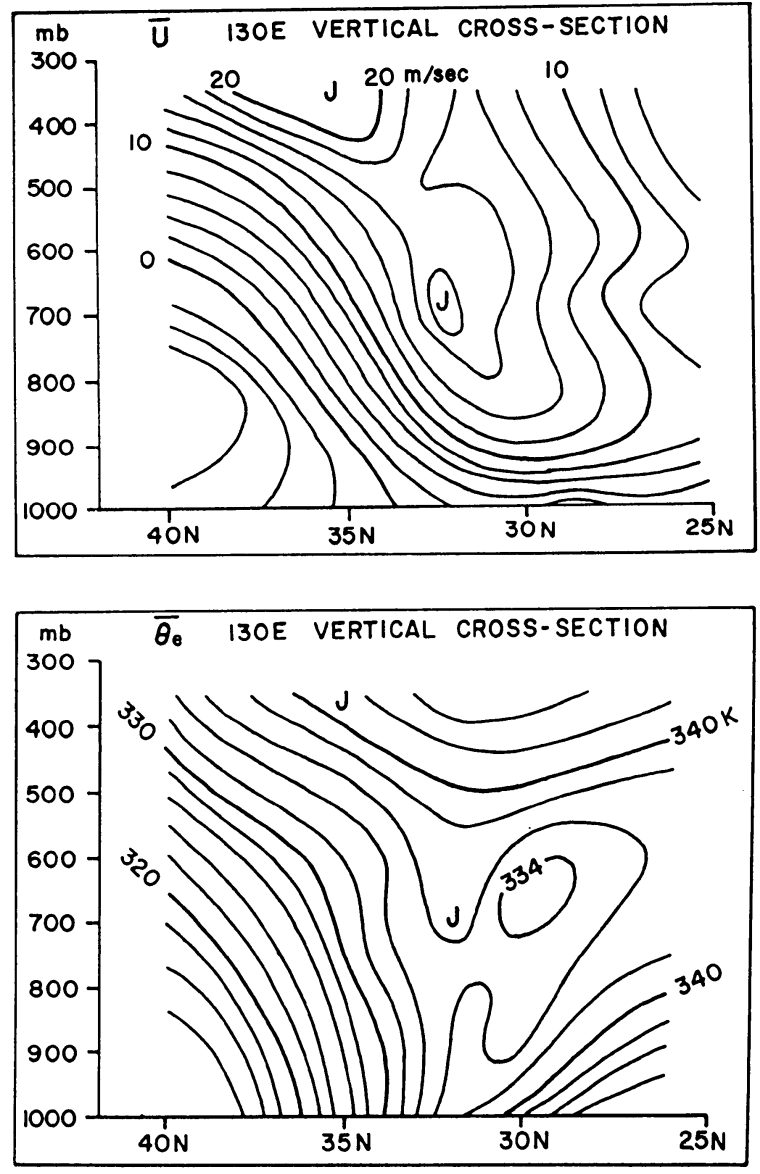

Fig. 20. Vertical cross section of u-component of wind velocity and equivalent potential temperature $\theta e$ averaged for 3-10 July 1969 along $130^{\circ} \mathrm{E}$ (Matsumoto et al., 1971).

Figure 21 is the $850 \mathrm{mb}$ map at 09 LST 27 June 1972. There is a weak cyclone $(1380 \mathrm{gpm})$ over the southwestern Japan Sea. Intense rainfalls occurs over Kyushu, about $200 \mathrm{~km}$ south from the cyclone. In the rainfall area, of $240 \mathrm{~mm}$ of precipitation concentrates into a 6 -hour period between 03 and 09 LST 27 June.

Figure 22 shows the PPI radar image obtained by Mt. Seburi radar and the vertical profiles of potential temperature $\theta$, equivalent potential temperature $\theta e$, saturation equivalent potential temperature $\theta e^{*}$, and wind velocity at the four upper observation stations (47-827, Kagoshima; 47-819, Kumamoto; 47807 , Fukuoka and the observation ship Keifu) which surround the intense rainstorm. Figure 22 depicts a mesoscale echo band extending from the East China Sea toward the heavy rainfall area over the western part of Kyushu. The SW-ly low-level jet stream forms in the vicinity of the heavy rainfall area. The largest wind speed at $900 \mathrm{mb}(\sim 40 \mathrm{knot})$ and $850 \mathrm{mb}$ ( $\sim 50 \mathrm{knot})$ is observed at $47-819$, which is located about $50 \mathrm{~km}$ southeast of the echo band, while the

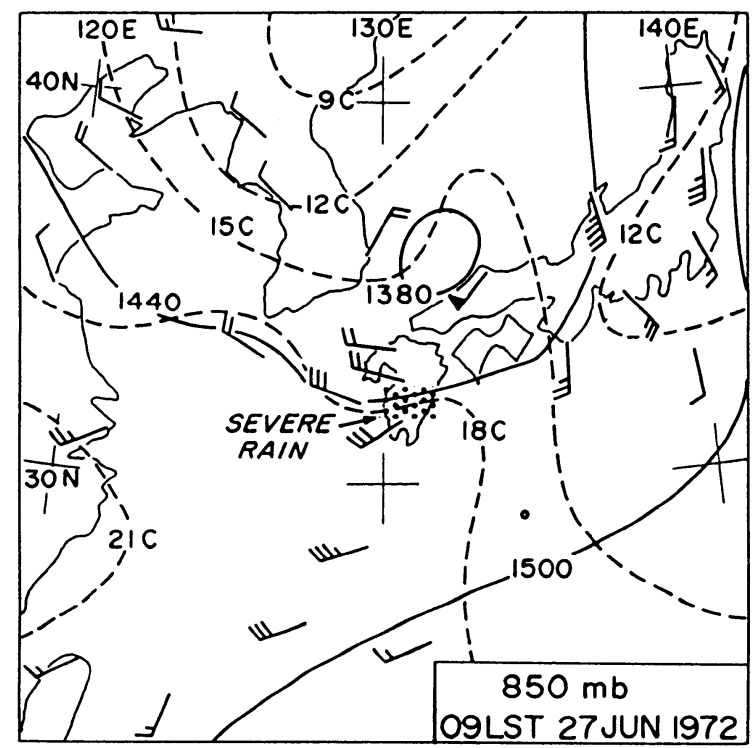

Fig. 21. The $850 \mathrm{mb}$ map at 09 LST 27 June 1972. The stippling indicates the intense rainfall area over Kyushu (Ninomiya, 1978).

largest wind speed at 800 and $700 \mathrm{mb}(\sim 55 \mathrm{knot})$ is observed at 47-807, which is at the northwest side of the echo band. This indicates that the vertical axis of the low-level jet tilts northwestward with height.

Figure 22 indicates the mesoscale region of convective instability. The most unstable condition exists just south of the echo band (Ship K), while a convectively stable condition is seen about $70 \mathrm{~km}$ ahead of the echo band (47-819). An almost neutral condition is observed within the echo band (47807 ), indicating the release of convective instability by convection.

Figure 23-A shows the vertical time section of the vertical p-velocity $(\omega)$ and the zonal wind component relative to the cyclone's movement (Ur). Figure 23-B depicts the meridional component of wind velocity $(\mathrm{V}) . \omega, \mathrm{Ur}$ and $\mathrm{V}$ are averaged over an area $\mathrm{S}$, which is enclosed by four stations $47-807,47-819$, 47-827 and Ship K,as shown in Fig. 22. The estimation of $\omega$ seems to be consistent with the variation of precipitation in the area $\mathrm{S}$ shown in Fig. 23-C. The values of $\omega$ and Ur suggest a vertical circulation around the low-level jet stream. In this case, the peak precipitation with maximum upward velocity appears after the passage of the low-level jet's core. This indicates that the peak precipitation and maximum upward motion occur to the northwest of the low-level jet stream.

Now we will refer back to Fig. 22, which shows convective instability to the south of the intense precipitation zone (Ship K). In contrast to the thunderstorms over the Midwest of the United States, the generation of convective instability in the Baiu front 
O3 LST 27 JUN 1972
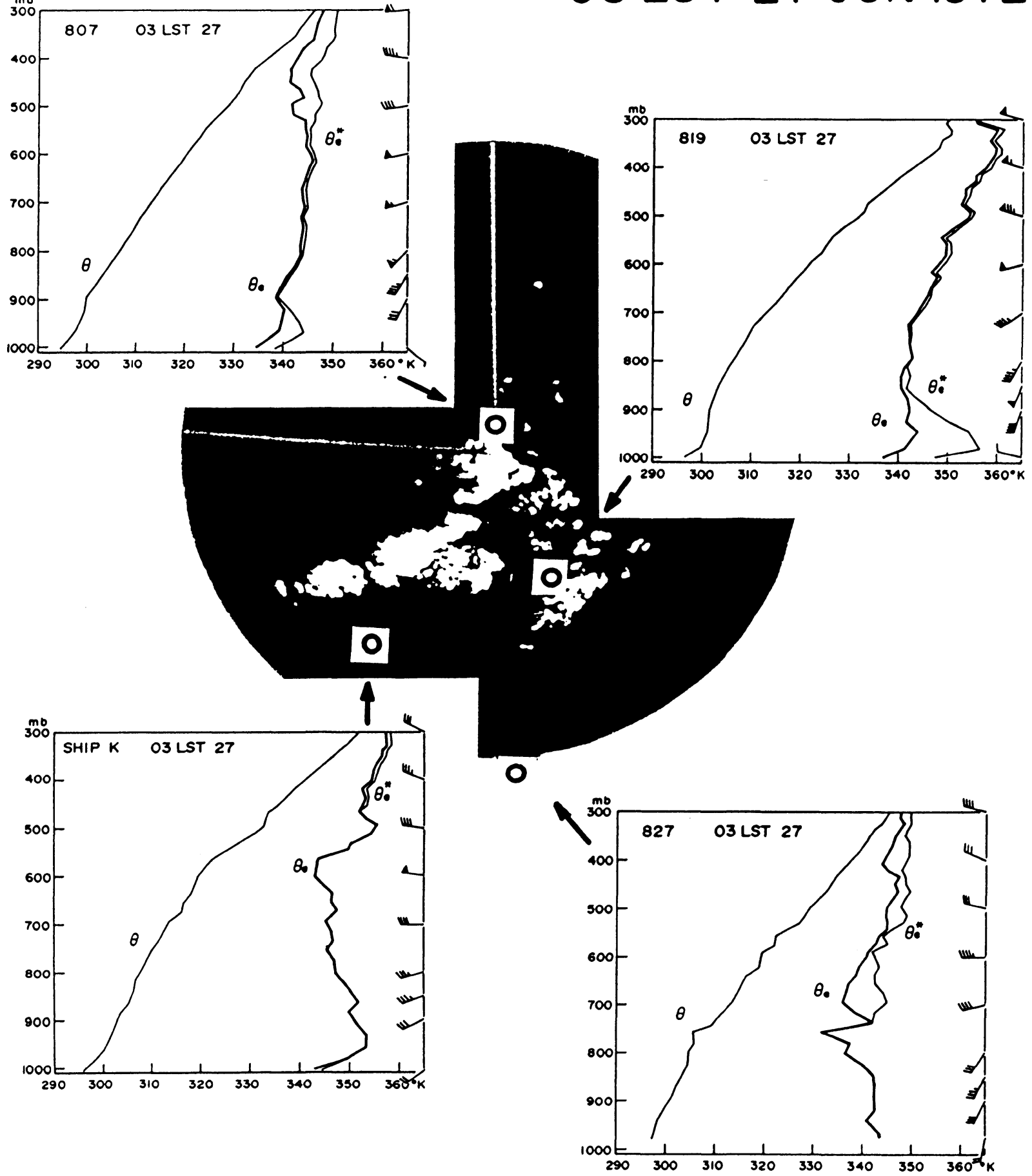

Fig. 22. The $200 \mathrm{~km}$ range PPI radar image of Mt. Seburi radar at 03 LST 27 June 1972 shows a mesoscale echo band over the intense precipitation area. The vertical distributions of potential temperature $\theta$, equivalent potential temperature $\theta e$, saturation equivalent potential temperature $\theta e^{*}$ and wind velocity at four upper observation stations (47-808, 47-819, 47-827 and Ship K) enclosing the intense rainfall area are presented (Ninomiya and Yamazaki, 1979).

is not due to cold, dry advection in the middle and upper troposphere. In the Baiu front, low-level warm and moist advections are the primary process for the generation of convective instability. We will examine the generation of convective instability quantitatively. The local time change of equivalent potential temperature $\theta e$ can be expressed as 
A
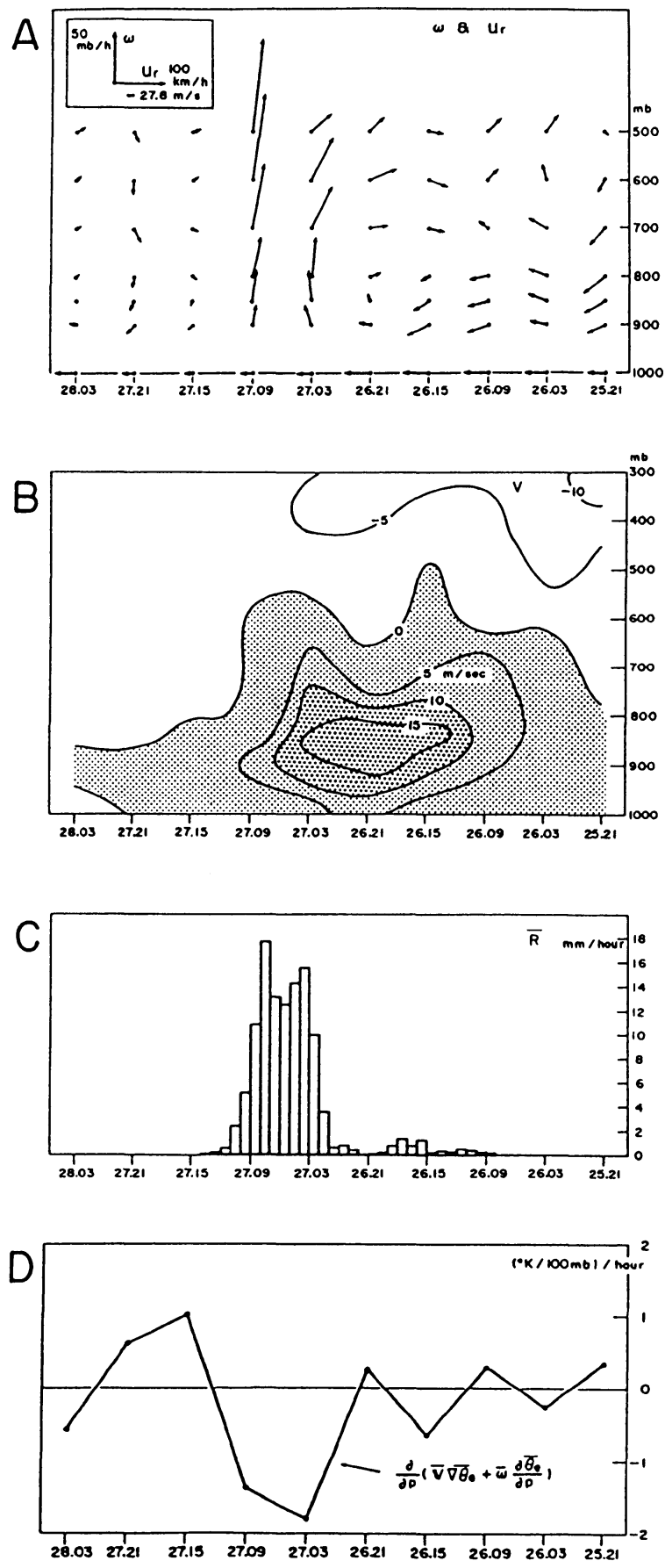

Fig. 23. Time series of several meteorological parameters evaluated over the area $\mathrm{S}$, which is enclosed by four stations (47-807, 47-819, 47-827 and Ship K) from 21 LST 25 to 03 LST 28 June 1972. A: The vertical-p-velocity $(\omega)$ and zonal wind component relative to the mesoscale depression's movement (Ur). B: Meridional wind component $(\mathrm{V})$. C: Hourly precipitation. D: $\partial A(\bar{\theta} e) / \partial p$ $\equiv \partial(\bar{v} \nabla \bar{\theta} e+\bar{\omega} \partial \bar{\theta} e / \partial p) / \partial p$ in $875-400 \mathrm{mb}$. (Ninomiya and Yamazaki, 1979).

$$
\frac{\partial \bar{\theta} e}{\partial t}+\left[\nabla(\overline{\boldsymbol{V} \theta e})+\frac{\partial}{\partial p}(\bar{\omega} \overline{\theta e})\right]+\frac{\partial \overline{\omega^{\prime} \theta e^{\prime}}}{\partial p}=0
$$

or

$$
\frac{\partial \bar{\theta} e}{\partial t}+\left[\overline{\boldsymbol{V} \nabla \theta} e+\bar{\omega} \frac{\partial \bar{\theta} e}{\partial p}\right]+\frac{\partial}{\partial p} \overline{\omega^{\prime} \theta e^{\prime}}=0 .
$$

That is

$$
\frac{\partial \bar{\theta} e}{\partial t}+A(\bar{\theta} e)+S(\bar{\theta} e)=0,
$$

where

$$
A(\overline{\theta e}) \equiv \overline{\boldsymbol{V} \nabla \theta} e+\bar{\omega} \frac{\partial \overline{\theta e}}{\partial p} \text { and } S(\overline{\theta e})=\frac{\partial}{\partial p} \overline{\omega^{\prime} \theta e^{\prime}}
$$

represent the $\theta e$ advection by grid-scale flow and the apparent source of $\theta e$ due to convection, respectively. The overbar $\left(^{-}\right)$and prime ()$^{\prime}$ indicate gridscale and subgrid (convective)-scale quantities, respectively. The local time change of $-\partial \overline{\theta e} / \partial p$ can be obtained as

$$
-\frac{\partial}{\partial t}\left(\frac{\partial \overline{\theta e}}{\partial p}\right)=\frac{\partial}{\partial p} A(\overline{\theta e})+\frac{\partial}{\partial p} S(\overline{\theta e}) .
$$

The first term on the right hand side of the equation expresses the differential advection, while the second term is for differential heating in $\theta e$. A negative value of $\partial A(\overline{\theta e}) / \partial p$, that is the warm-moist advection in the lower layer with the cold-dry advection in the higher level, implies the destabilization of the layer. The second term $\partial S(\overline{\theta e}) / \partial p$ generally is positive in the convective area, since an upper-level apparent heat source contrasts with a low-level apparent sink of $\theta e$. The differential heating effect stabilizes the layer. Figure 23-D shows the time change of $\partial A(\overline{\theta e}) / \partial p$ evaluated for a $875-400 \mathrm{mb}$ layer over the area $S$ of about $(100 \mathrm{~km})^{2}$ dimension enclosed by the four upper-air observation stations. It is evident that the intense precipitation takes place concurrently with the generation of convective instability by differential advection.

Figure 24 shows the vertical profile of apparent sink (source) of equivalent potential temperature evaluated over the area $S$ for 03-09 LST 27 June 1972 , i.e., the period of peak precipitation. The magnitude of the upper-level apparent heat source and the low-level apparent sink of $\theta e$ are evaluated as $3 \mathrm{~K} /$ hour and $-3 \mathrm{~K} /$ hour, respectively, in the budget analysis of $\theta e$. The balance between the generation of convective instability due to the advection process and the continuous release of convective instability due to convection maintains the moist neutral layer in the heavy rainfall area. 


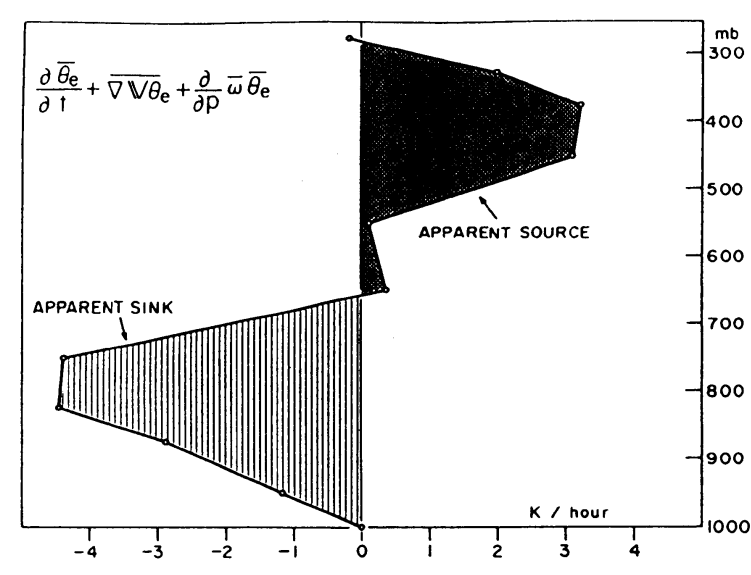

Fig. 24. Vertical profile of apparent sink (source) of equivalent potential temperature $d \theta e / d t \equiv \partial \bar{\theta} e / \partial t+\nabla(\overline{v \theta e})+\partial / \partial p(\bar{\omega} \bar{\theta} e)$ evaluated over the area $\mathrm{S}$ for 03-09 LST 27 June 1972 (Ninomiya and Yamazaki, 1979).

\section{Statistical features of disturbances in and around Baiu front}

Several case studies showed that the Baiu rainfalls over Japan are mainly caused by mesoscale organized cloud systems associated with Baiu frontal depressions (e.g., Matsumoto et al., 1970; Ninomiya and Akiyama, 1971, 1974; Yoshizumi, 1977; Akiyama, 1978). It has been reported that many vortices form over the Tibetan Plateau during the summer monsoon, and some of them move eastward and bring rainfalls over the central China (Tao and Ding, 1981; Tao and Chen, 1986; Kuo et al., 1986; Chen and Dell'Osso, 1984; Murakami and Huang, 1984; Ma and Bosart, 1987). Ninomiya et al. $(1981,1989 \mathrm{a}, \mathrm{b})$ and Akiyama (1984a, b) studied a long-lived cloud cluster which formed at the eastern foot of the Tibetan Plateau and caused intense rainfalls over China and Japan.

Akiyama $(1989,1990 \mathrm{a}, \mathrm{b})$ studied the statistical features of the disturbances in and around the Baiu frontal zone during July 1982 by using GMS IR data and the FANL (objective analysis of Finemesh Analysis; $254 \mathrm{~km}$-mesh at $60^{\circ} \mathrm{N}$ ) data. In the present section, we will summarize briefly the results of Akiyama (1989, 1990a, b).

Figure 25 shows the 31-day (July 1982) averaged amount of high-cloud $\left(C_{H}\right)$, whose top is higher than $400 \mathrm{mb}$. The stippled and blacked areas show $C_{H}$ larger than 40 and $50 \%$, respectively. The zone of large $C_{H}$ extending along $30^{\circ} \mathrm{N}$ latitude circle is the Baiu frontal zone.

Figure 26 presents the 31-day averaged temperature and relative vorticity fields at 700 and $300 \mathrm{mb}$. On these maps, the heavy dashed line indicates the position of the Baiu frontal cloud zone shown in Fig.

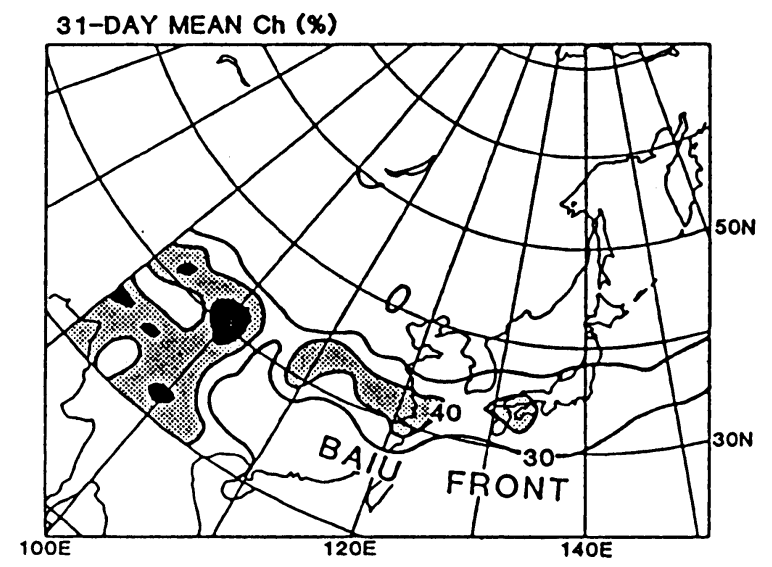

Fig. 25. The 31-day (1-31 July 1982) averaged high-cloud amount $\left(C_{H}\right.$ : cloud top higher than $400 \mathrm{mb}$ level). The stippled and blacked area shows $C_{H}$ larger than 40 and $50 \%$ respectively (Akiyama, 1990a).

25. As discussed in the previous sections, the western part of the Baiu front in $100-120^{\circ} \mathrm{E}$ is not associated with the strong thermal gradient in the lower troposphere. The low-level thermal gradient is fairly strong in the Baiu frontal zone in $130-160^{\circ} \mathrm{E}$. The zone of maximum thermal gradient at $300 \mathrm{mb}$, which corresponds to the polar frontal zone, extends along $\sim 40^{\circ} \mathrm{N}$. The $200 \mathrm{mb}$ jet stream axis is seen over the zone of maximum thermal gradient at $300 \mathrm{mb}$.

At $700 \mathrm{mb}$, the zone of maximum vorticity coincides approximately with the Baiu frontal cloud zone. This is consistent with the fact that the lowlevel jet stream extends along the south side of the Baiu frontal cloud zone. At $300 \mathrm{mb}$, the zone of maximum vorticity, which is along the north side of the high-level jet stream, extends along a $50^{\circ} \mathrm{N}$ latitude circle in $70-100^{\circ} \mathrm{E}$. The zone shifts southward in $100-110^{\circ} \mathrm{E}$ and extends along a $40^{\circ} \mathrm{N}$ circle in $120-160^{\circ} \mathrm{E}$.

In $100-120^{\circ} \mathrm{E}$, the zone of maximum $\zeta$ at $700 \mathrm{mb}$ is separated from the zone of maximum $\zeta$ at $300 \mathrm{mb}$. The distance between them is about $1500 \mathrm{~km}$. In other words, the Baiu front in $100-120^{\circ} \mathrm{E}$ indicates a shallow structure, that is the vorticity is confined to the lower layers. In $135-160^{\circ} \mathrm{E}$, the zone of maximum $\zeta$ at $300 \mathrm{mb}$ (the polar front) approaches the zone of maximum $\zeta$ at $700 \mathrm{mb}$ (the Baiu front) on the horizontal projection. In other words, the Baiu front in $135-160^{\circ} \mathrm{E}$ shows the structure of a typical polar front, where the vertical axis of the vorticity tilts northward with height. The area in $120-135^{\circ} \mathrm{E}$ is the transitional zone separating the western Baiu front with its shallow structure and the eastern Baiu front with its deep baroclinic structure.

The aforementioned descriptions are for the Baiu front and the polar front in the time-averaged field for July 1982. It should be mentioned that the loca- 
31-DAY MEAN TEMP.
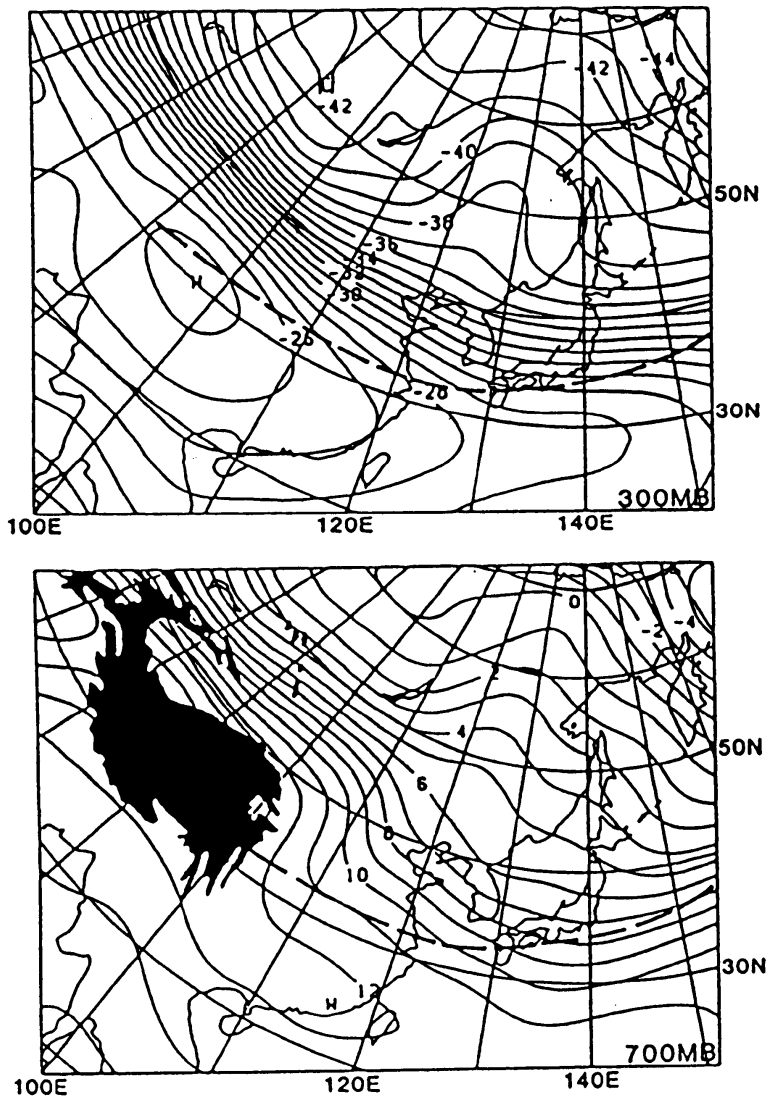

31-DAY MEAN RELATIVE VORTICITY
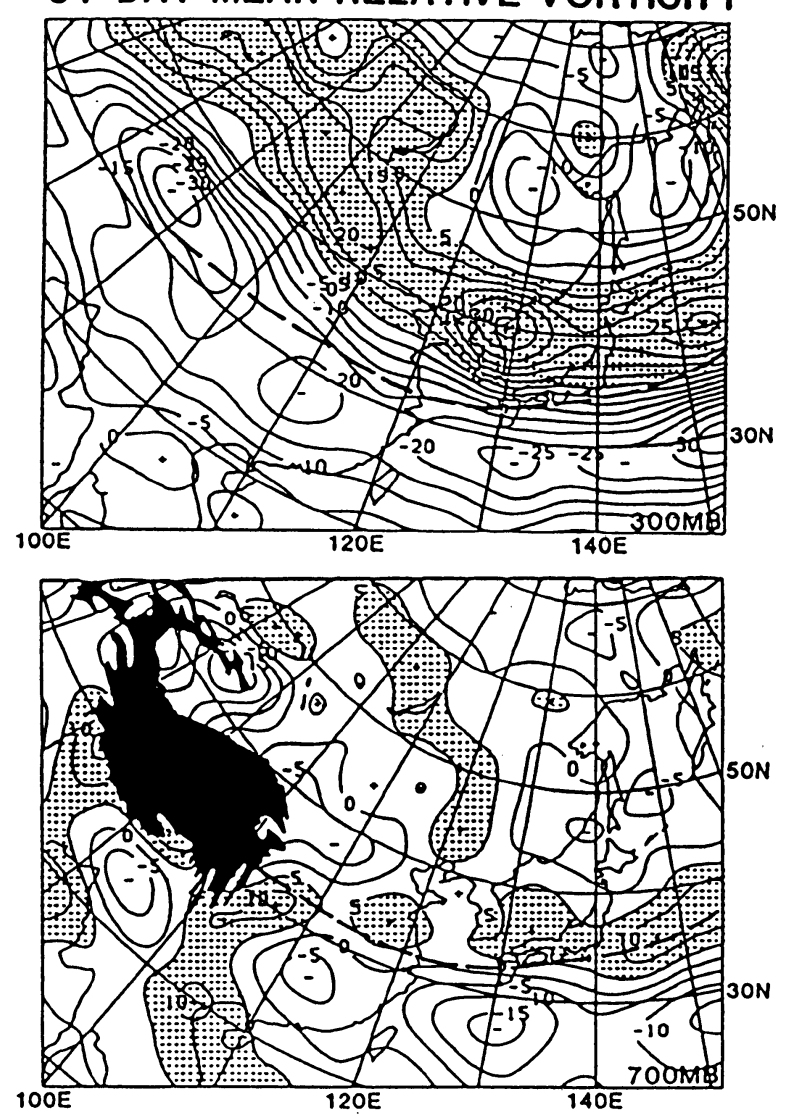

Fig. 26. The 31-day averaged temperature and relative vorticity fields at 700 and $300 \mathrm{mb}$. The heavy broken line represents the Baiu frontal cloud zone shown in Fig. 25 (Akiyama, 1990a).

tion and structure of these fronts varied, of course, from day to day (Akiyama, 1990a).

We next study the behaviour of the disturbances in July 1982 by tracing the vorticity maximum $\left(\zeta_{\max }\right)$ at $300,500,700$ and $850 \mathrm{mb}$ at 12 -hour intervals. Many of these $\zeta_{\max }$ are found in the polar and Baiu frontal zone. Generally speaking, the disturbances in the polar frontal zone have a deep structure. That is, the vorticity maximum is seen throughout the troposphere, and the magnitude of the vorticity increases with height. In $100-130^{\circ} \mathrm{E}$, the vorticity maximum of the Baiu frontal disturbances is limited in the lower troposphere. In 140$160^{\circ} \mathrm{E}$, the Baiu frontal disturbances indicate, however, a deep structure with a northward tilt of the vorticity axis with height.

The Baiu frontal disturbances, which are identified as the vorticity maxima, are associated with organized cloud systems. As an example, the map of cloud mean $T_{B B}\left(T_{B B}\right.$ : cloud top temperature estimated from GMS IR observation) at 00 GMT 17 July 1982 is presented in Fig. 27. Hereafter, the "cloud mean $T_{B B}$ " is abbreviated as $T_{B B}$. In this map, $T_{B B}$ isotherms are given at $10^{\circ} \mathrm{C}$ interval.

The $\zeta_{\max }$ at 700 and $300 \mathrm{mb}$ are indicated on the $T_{B B}$ map. In Fig. 27, $\mathrm{N}$ and $\mathrm{B}$ indicate the $\zeta_{\max }$ in

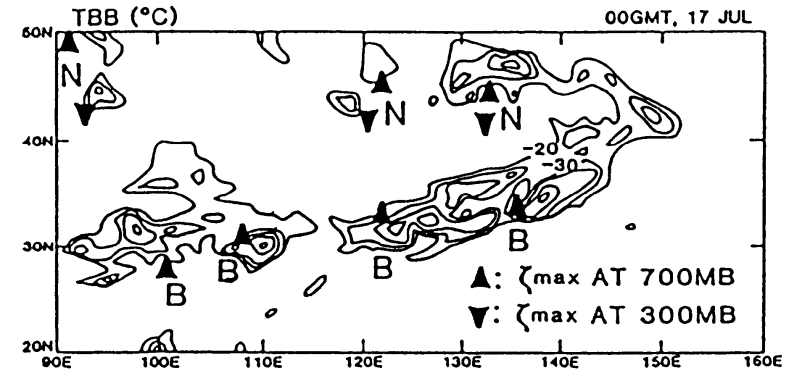

Fig. 27. $T_{B B}$ map for 00 GMT 17 July 1982. The vorticity maxima $\left(\zeta_{\max }\right)$ at 700 and $300 \mathrm{mb}$ are indicated on the map. $\mathrm{N}$ and $\mathrm{B}$ show the $\zeta_{\max }$ in the northern (polar) and Baiu frontal zone, respectively (Akiyama, 1990a).

the northern (polar) and the Baiu frontal zone, respectively. The $\mathrm{N}$ disturbances show a deep structure, while the $\mathrm{B}$ disturbances have a shallow structure. In $90-120^{\circ} \mathrm{E}$, the Baiu frontal zone is separated from the northers frontal zone. Both frontal zones begin to marge around $140^{\circ} \mathrm{E}$. At 00 GMT 17 July 1982 , one leading $\mathrm{N}$ disturbance and four successive $\mathrm{B}$ disturbances form, as a whole, a long $(\sim 5000 \mathrm{~km})$ 

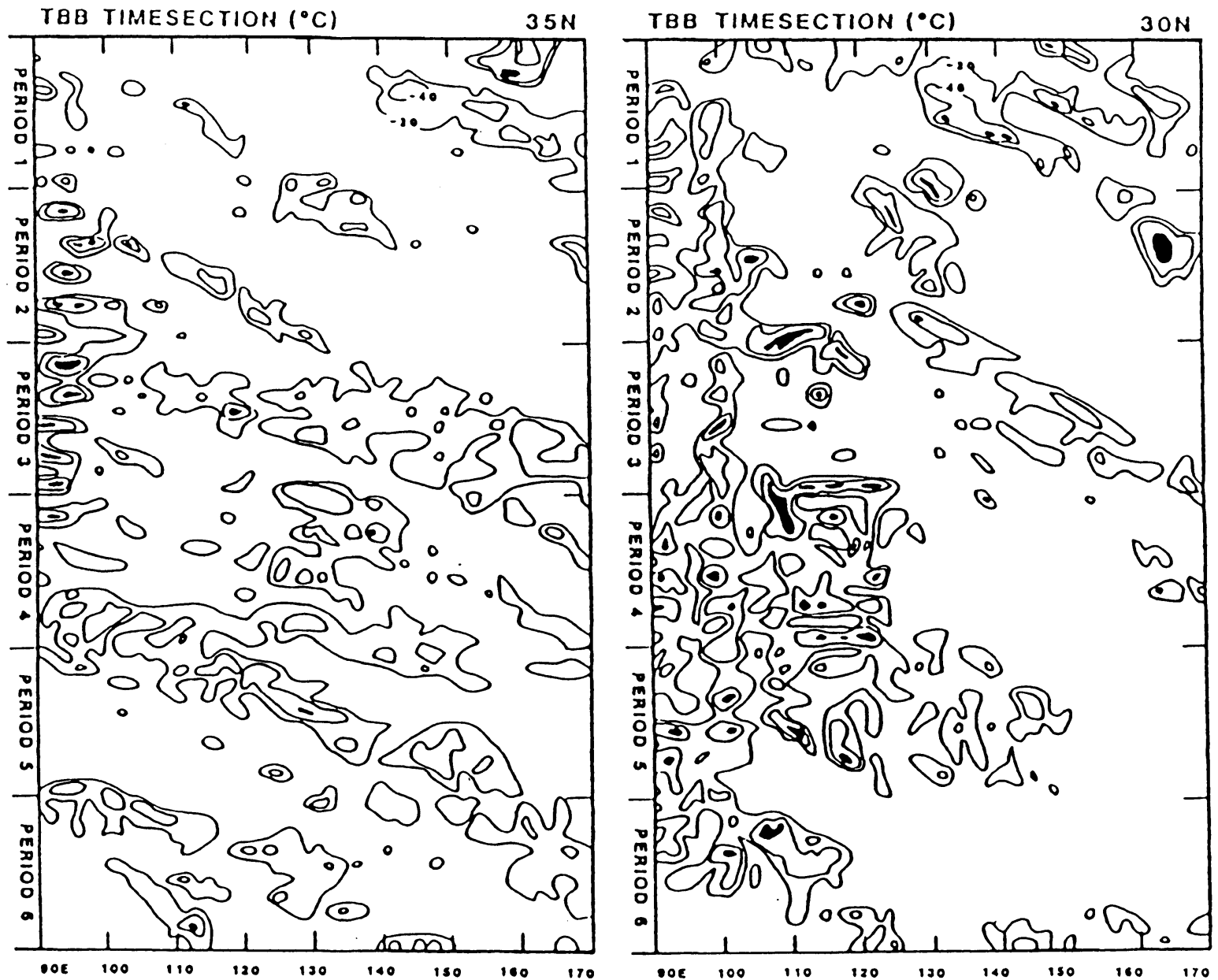

Fig. 28. The time-longitude section of $T_{B B}$ along 30 and $35^{\circ} \mathrm{N}$ latitude circles for July 1982. The $T_{B B}$ isotherms of $-20,-40$ and $-60^{\circ} \mathrm{C}$ are given. The blacked areas represent the areas of $T_{B B}$ colder than $-60^{\circ} \mathrm{C}$ (Akiyama, 1989).

cloud system of the mesoscale cyclone family. This presents a typical situation on the Baiu front.

We next study the mesoscale cloud systems in the Baiu frontal zone. The longitude-time sections of $T_{B B}$ along 30 and $35^{\circ} \mathrm{N}$ circles for July 1982 are presented in Fig. 28. The $T_{B B}$ isotherms of -20 , -40 and $-60^{\circ} \mathrm{C}$ are shown. The blacked areas represent areas of $T_{B B}$ lower than $-60^{\circ} \mathrm{C}$. The eastward propagation of the Baiu frontal cloud systems with intervals of a few days are clearly seen. The significant diurnal variation of $T_{B B}$ is seen around $90-110^{\circ} \mathrm{E}$ along a $30^{\circ} \mathrm{N}$ circle.

In order to study the statistical features of the disturbances, Akiyama (1989) performed a spectral analysis of the high-cloud amount $\left(C_{H}\right)$ averaged over each $2^{\circ}$ Lat $\times 2^{\circ}$ long area. The result of the spectral analysis shows that the spectral density of $C_{H}$ is large at $\sim 6, \sim 3.5$ and $\sim 2.5$-day periods in $120-170^{\circ} \mathrm{E}$, while the diurnal variation is very large in $90-100^{\circ} \mathrm{E}$.

The distribution of the spectral density of $C_{H}$ for period of 5.86-, 2.41- and 1.00-day are presented in Fig. 29. The zone of high spectral density for the 5.86-day period (upper panel) coincides approximately with the northern (polar) frontal zone. This indicates that the synoptic-scale disturbances are predominant in the polar frontal zone. The area of high spectral density for the 2.41-day period (middle panel) coincides approximately with the Baiu frontal zone. This is consistent with the conclusion of many case studies: that the meso- $\alpha$-scale cloud clusters develop frequently in the Baiu frontal zone. The bottom panel of Fig. 29 shows that the diurnal variation of $C_{H}$ is very large around the south-eastern foot of the Tibetan Plateau.

The cloud systems and/or cloud clusters are usually associated with the disturbances which appear as $\zeta_{\max }$ in the vorticity maps. We next discuss the spectral analysis of the relative vorticity which is obtained from wind data of the $254 \mathrm{~km}$-mesh objective analysis. Although the peak period of the spectral density of $\zeta$ varies place to place, and level to level, the spectral density is large, in general, at $\sim 6-$, $\sim 3.5-, \sim 2.5$ - and 1.0-day periods. This is consistent 

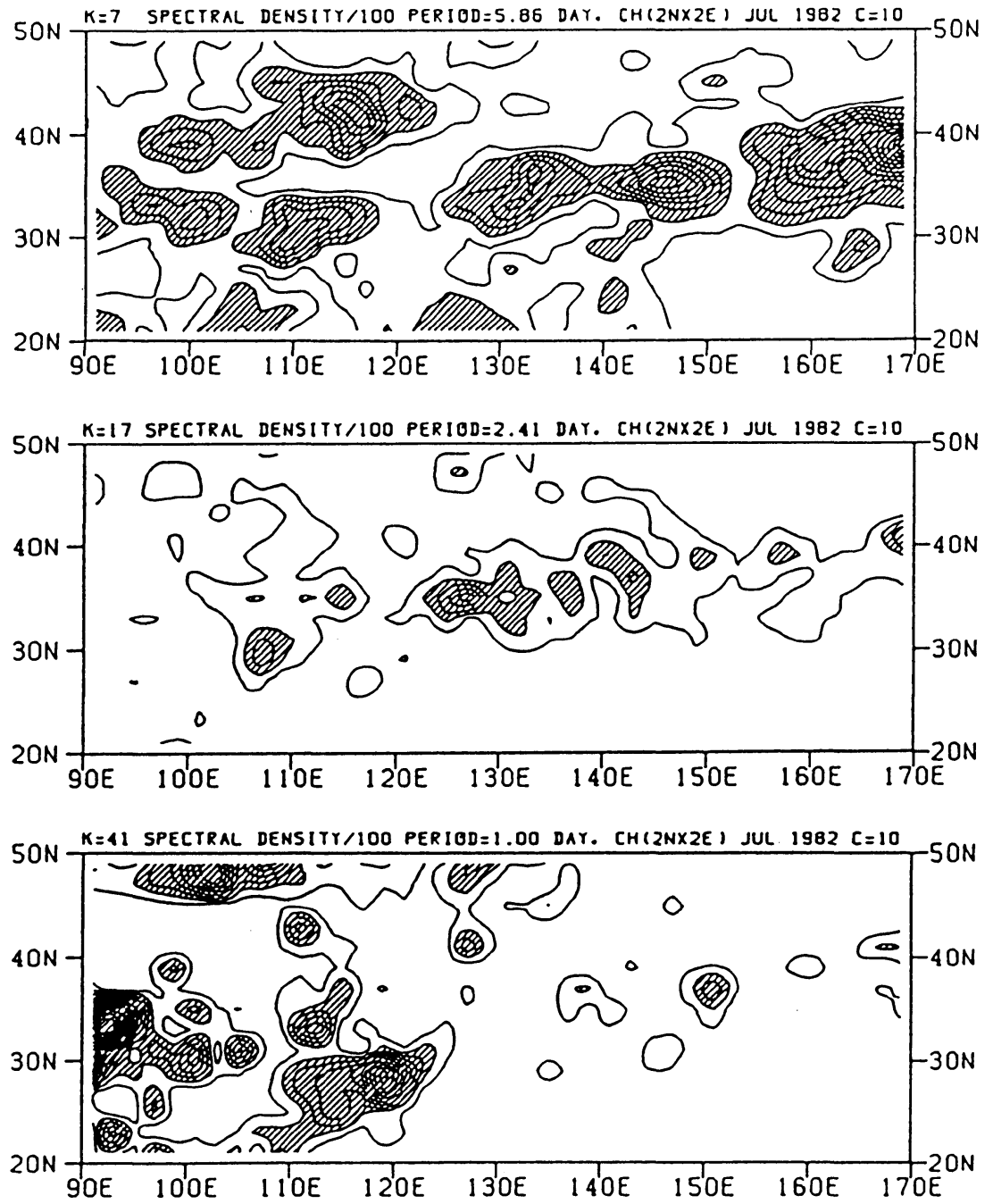

Fig. 29. The distribution of the spectral density of $C_{H}$ for periods of 5.86-, 2.41- and 1.00-days. Hatched areas represent spectral density greater than $2000(\%)^{2}$.day. (Akiyama, 1989).

with the results of the spectral analysis of $C_{H}$. The features of disturbances of $\sim 6$ - and $\sim 2.5$-day period will be studied in more detail.

The distribution of the spectral density of vorticity at $300 \mathrm{mb}\left(\zeta_{300}\right)$ and that of specific humidity at $500 \mathrm{mb}\left(q_{500}\right)$ for a 5.86-day period are presented in the top and bottom panel of Fig. 30, respectively. The phase lines are also given in the maps. The zone of large spectral density of $\zeta_{300}$ in $40-50^{\circ} \mathrm{N}$ is related to the synoptic-scale disturbances in the polar frontal zone. Although the zone of large spectral density of $\zeta$ is seen in the middle and upper troposphere, the spectral density of $\zeta$ is smaller in the lower-layer (map is not shown). The vertical phase lines obtained by the spectral analysis (a figure is not presented) indicates that the polar frontal disturbances with a 5.84-day period have a baroclinic wave structure, that is, the vertical axis of vorticity tilts westward with height.

The zone of maximum spectral density of $q_{500}$ extends along the south side of that of $\zeta_{300}$. This agrees with the observed feature that the specific humidity in the lower-middle troposphere is large in the southeastern part of the polar frontal disturbances. It must be noted that the polar frontal disturbances control the moisture in the Baiu frontal zone.

The distribution of spectral density of $\zeta_{300}, \zeta_{700}$ and $q_{700}$ for a 2.41-day period is presented in the top, middle and bottom panels of Fig. 31, respectively. The phase lines are also given.

The zone of maximum spectral density of $\zeta_{300}$ extends along the polar frontal zone. The spectral density of $\zeta_{300}$ increases east-ward and is maximized around $120^{\circ} \mathrm{E}$. There are two zone of maximum spectral density of $\zeta$ at $700 \mathrm{mb}$. One extends along the polar frontal zone around $45^{\circ} \mathrm{N}$, and another extends along the Baiu frontal zone from $120^{\circ} \mathrm{E}$ to $160^{\circ} \mathrm{E}$. While the disturbances in the polar frontal zone show a deep structure, the disturbances in the Baiu frontal zone show a shallow structure. The phase lines indicate that the disturbances in the polar and 

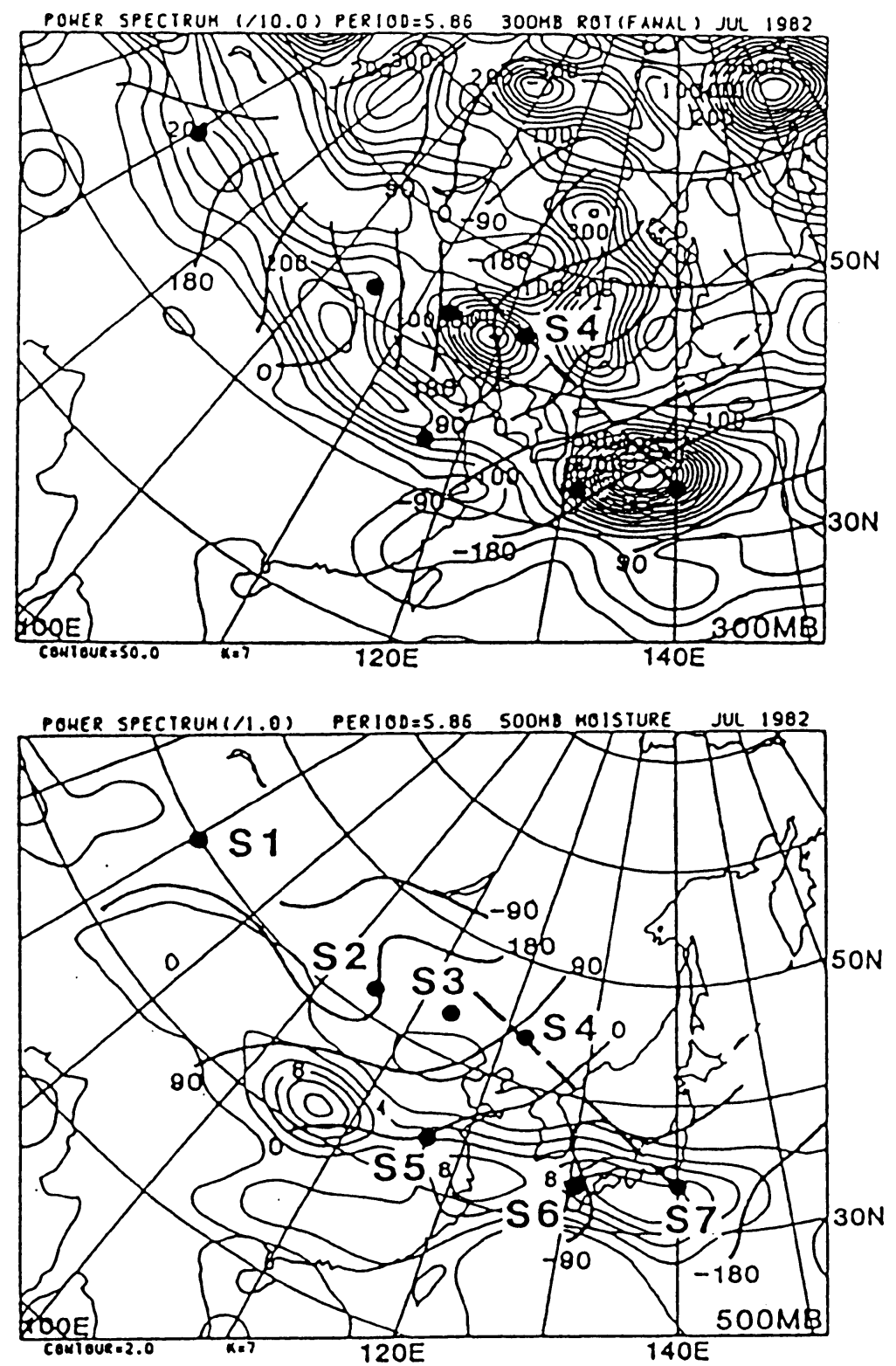

Fig. 30. Top panel: The distribution of the spectral density of $\zeta_{300}$ for a 5.86-day period. The isolines of density are given with $50 \times 10 \times\left(10^{-6} / \mathrm{sec}\right)^{2}$ day interval. The phase lines are also given. Bottom panel: The distribution of the spectral density of $q_{500}$ for a 5.86-day period. The isolines of density are given with $2 \times \mathrm{cgr} / \mathrm{kgr})^{2}$ day interval. The phase lines are given. (Akiyama, 1990b).

Baiu frontal zones are in phase. The Baiu frontal disturbances seem to develop under the influence of the polar frontal disturbances which propagate from the west. The propagation of the Baiu frontal disturbances is also clearly seen in the map of the spectral density of $q_{700}$ for a 2.41 -day period (bottom panel of Fig. 31).

Figure 32 represents the vertical phase structure in the vorticity and moisture field obtained at four grid points (see the position of the grid points in Fig. 31 ). In the lower troposphere of the Baiu front, the vorticity and the moisture axes tilt eastward with increasing height. The vorticity axis tilts westward in the troposphere above $500 \mathrm{mb}$. The anticyclonic circulation (negative vorticity) appears above the moisture maximum around $500 \mathrm{mb}$. The structure of the disturbance for a 2.41-day period obtained by the spectral analysis is consistent with the results in the case studies of the Baiu frontal meso$\alpha$-scale depressions (Ninomiya and Akiyama, 1971, 1972, 1973; Ninomiya et al., 1981).

Thus far, we have shown, in the spectral analysis on vorticity, specific humidity and cloud amount, that synoptic-scale and meso- $\alpha$-scale disturbances are predominant in the polar and Baiu frontal zone during July 1982. The interaction between them 

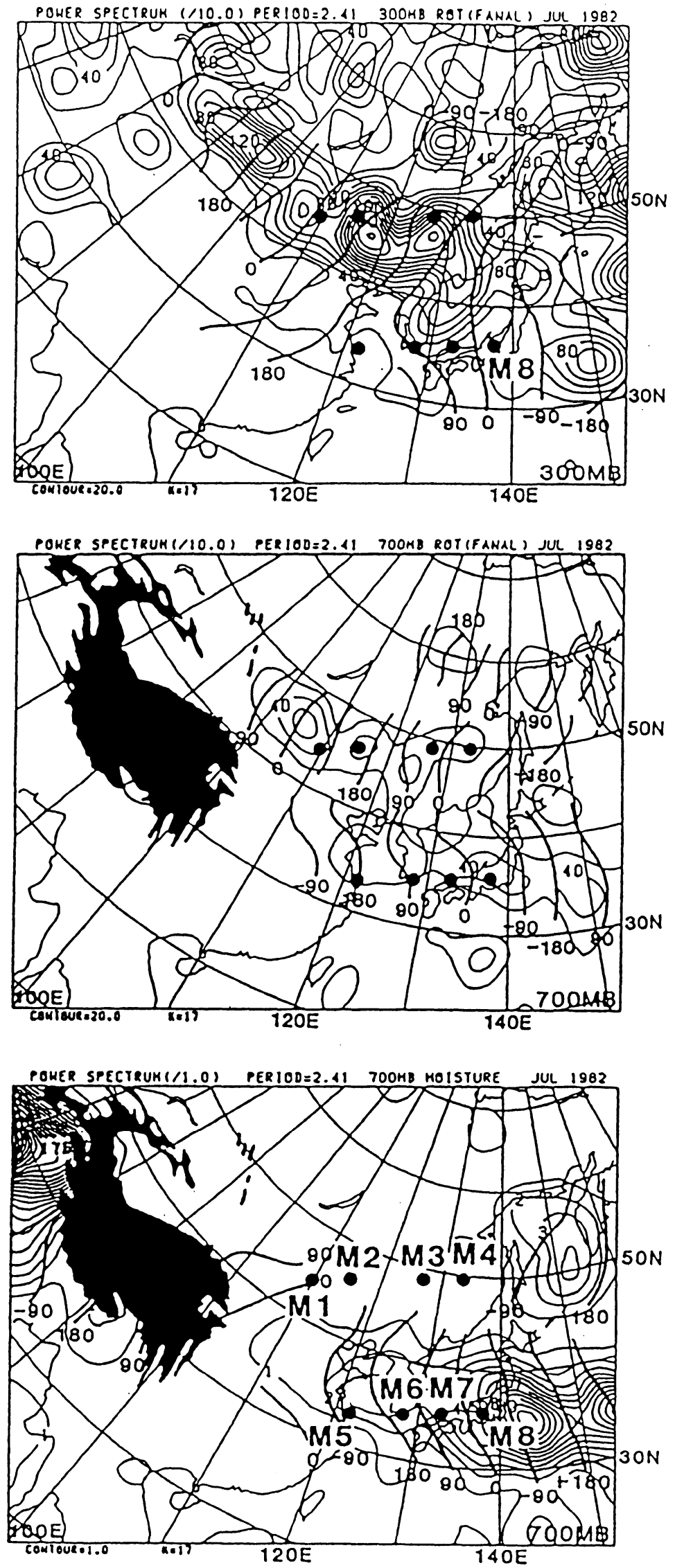

Fig. 31. The distribution of the spectral density of $\zeta_{300}, \zeta_{700}$ and $q_{700}$ for a 2.41-day period. The isolines at density are given with $20 \times 10 \times\left(10^{-6} / \mathrm{sec}\right)^{2}$ day and $1 \times(\mathrm{gr} / \mathrm{kgr})^{2}$ day interval, respectively. Phase lines are given. (Akiyama, 1990b). 
2.41-day perlod, VOR. \& MIX. RATIO (BAIU FRONT)

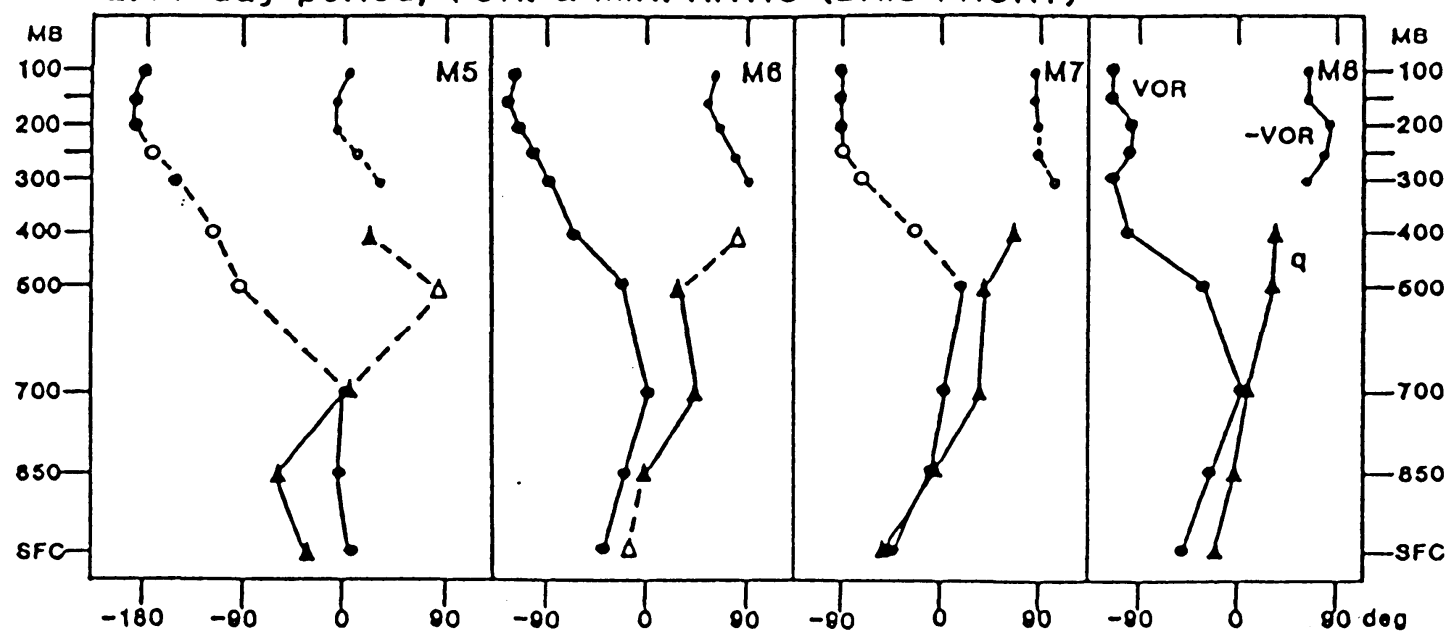

Fig. 32. Vertical phase structure of the disturbance for a 2.41-day period in the vorticity and specific humidity field obtained for several grid points (see bottom panel in Fig. 31 for the location of the grid points). (Akiyama, 1990b)

is to be noted. The meso- $\alpha$-scale Baiu frontal disturbances tend to develop when the disturbances in the polar frontal zone approach $\sim 120^{\circ} \mathrm{E}$. They form a mesoscale cyclone family of $\sim 5000 \mathrm{~km}$ length as shown Fig. 27. However, the processes of interaction between them are complicated and vary from case to case. More detailed case studies are needed.

\section{Meso- $\beta$ - and meso- $\gamma$-scale features of Baiu precipitation}

We have already pointed out that the intense Baiu precipitation concentrates within a short time span and narrow area (Fig. 6). Such intense precipitation is usually associated with the meso- $\beta$ - or meso$\gamma$-scale convective system within the meso- $\alpha$-scale Baiu frontal disturbance. In the present section, some examples of the meso- $\beta$ - and meso- $\gamma$-scale fine structure of Baiu precipitation will be presented.

The top panel of Fig. 33 shows the ESSA-5 composite cloud image for 9 July 1968. A few meso- $\alpha-$ scale cyclones with their respective cloud clusters are aligned along the Baiu front. The bottom panel of Fig. 33 is the composite radar echo map for a meso$\alpha$-scale cyclone at 0449 LST 10 July 1968 . While the continuous precipitation echoes cover the northeastern quadrant of the meso- $\alpha$-scale cyclone, three meso- $\beta$-scale convective echo systems develop in the south-southwestern part of the cyclone. The meso$\beta$-scale system is decomposed into meso- $\gamma$-scale echo cells.

Sometimes, the Baiu frontal meso- $\alpha$-scale cloud system indicates a feature, on the satellite cloud image, similar to the MCC (meso-scale convective complex over the U.S.A.; Maddox, 1979). The top panel of Fig. 34 is the $T_{B B}$ map of a long-lived Baiu frontal cloud cluster at 0533 LST 15 July 1979. The
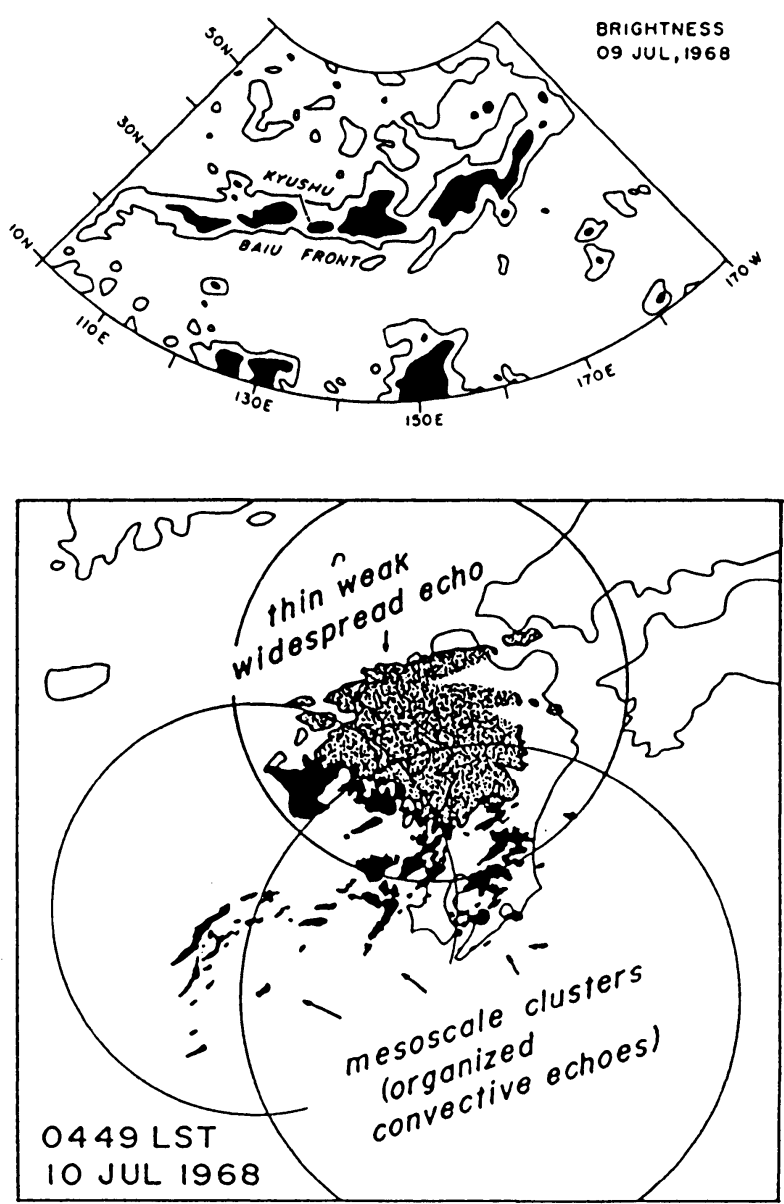

Fig. 33. Top panel: ESSA-5 composited cloud brightness map for 9 July 1968. Blacked areas indicate bright areas. Bottom panel: Illustration of the radar echo in a meso$\alpha$-scale depression for 0449 LST 10 July 1968. (Akiyama, 1978a) 

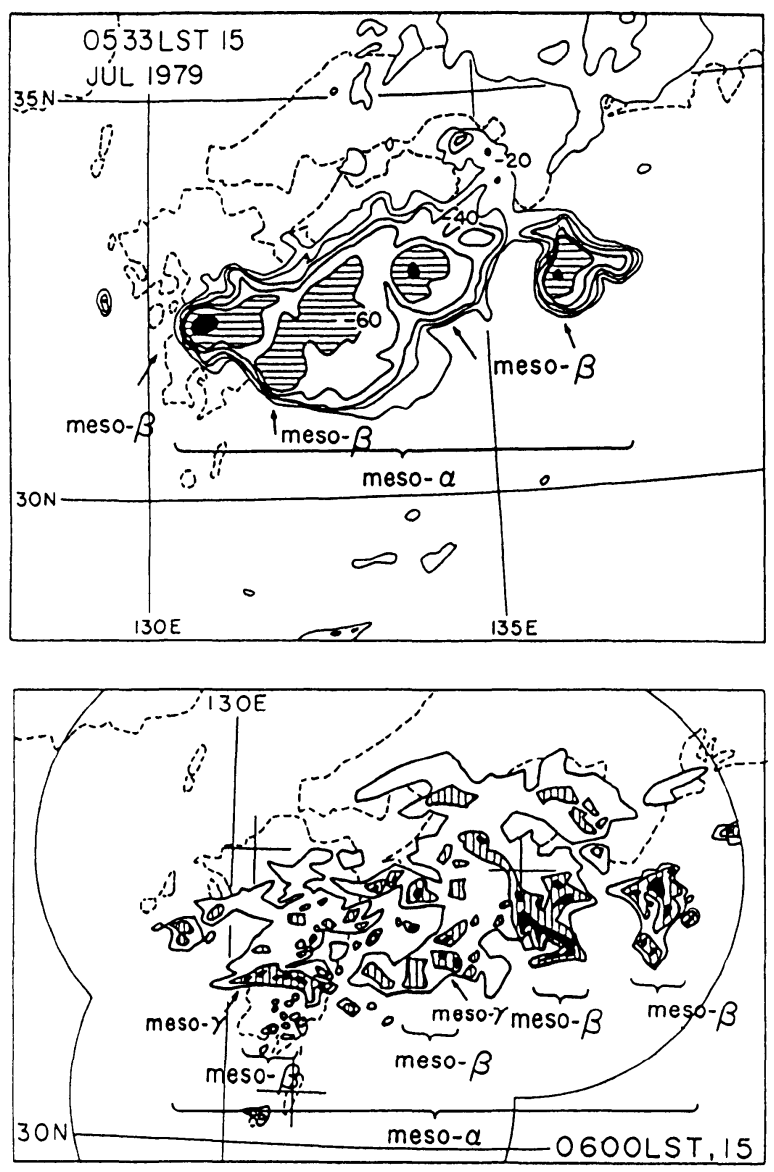

Fig. 34. Top panel: Schematic illustration of the meso- $\beta$-scale fine structure of a meso$\alpha$-scale Baiu frontal cloud cluster on a $T_{B B}$ map at 0533 LST 15 July 1979 . Bottom panel: Schematic illustration of the meso- $\beta$ - and meso- $\gamma$-scale fine structure of the meso- $\alpha$-scale Baiu frontal cloud cluster on a radar echo map at 06 LST 15 July 1979. The blacked, hatched and open ares indicates area of precipitation of $64-16$, 16-4 and 4-1 mm/hour respectively. (Ninomiya, Akiyama and Ikawa, 1988a).

horizontal extent of the cloud cluster is $\sim 500 \mathrm{~km}$ in $\mathrm{E}-\mathrm{W}$ and $\sim 300 \mathrm{~km}$ in S-N, which is the characteristic size of the meso- $\alpha$-scale (Orlanski, 1975). There are a few meso- $\beta$-scale cloud areas where $T_{B B}$ is colder than $-60^{\circ} \mathrm{C}$. This indicates that the meso$\alpha$-scale cloud cluster consists of a few meso- $\beta$-scale convective systems. While the pre-existing meso- $\beta$ scale system decays, new meso- $\beta$-scale system forms in the meso- $\alpha$-scale cloud cluster. Consequently, the meso- $\alpha$-scale cloud cluster, as a whole, is sustained for a few days (Akiyama, 1984a; Ninomiya et al., 1988a). The multi-radar composite echo map (the bottom map in Fig. 34 ) shows that the meso- $\beta$-scale systems are further decomposed into a few meso- $\gamma$ scale convective systems.
The mesoscale fine structures of the precipitation are commonly seen in many cases of the intense Baiu rainfall events over Japan.

\section{Concluding remarks}

This review paper summarizes the authors' recent studies on the "Baiu phenomena" over the Japan Islands and the adjacent areas.

In Section 2, the overall features of the Baiu were described. The most important feature of the Baiu is the formation of the Baiu front, which is a long quasi-stationary precipitation zone extending from the southeastern foot of the Tibetan Plateau to Japan and further to the northwestern Pacific.

The planetary- and large-scale circulations in the Baiu season were studied in Section 3 and 4. The cold Baiu trough, the polar front and the Pacific subtropical anticyclone are the major circulation systems which have influence on the Baiu front. The frontogenesis and the generation of convective instability by the southwesterly flow along the northwestern periphery of the Pacific subtropical anticyclone are the primary factors for formation of the Baiu front. The northerly wind in the rear of the Baiu trough and the Tibetan Plateau prevents the northward intrusion of the tropical airmass and sustains the Baiu frontal zone.

The structure of the Baiu front and the associated Baiu low-level jet stream in the peak Baiu period over the southwestern Japan were studied in Section 5 . The water vapor budget within the Baiu frontal zone was also shown.

The vertical circulation around the low-level SWly jet stream, the generation and the release of the convective instability in the intense Baiu rainfalls area were studied in Section 6 .

In Section 7, the statistical features of disturbances in and around the Baiu frontal zone were studied by the spectral analysis of cloud amount, relative vorticity and specific humidity. The results of the spectral analysis indicate that the meso- $\alpha$ scale disturbances develop in the Baiu frontal zone, while synoptic-scale disturbances prevail in the polar frontal zone. Influence of the polar frontal disturbances on the Baiu frontal disturbances was noted. The meso- $\beta$ - and meso- $\gamma$-scale fine structures of the meso- $\alpha$-scale disturbances were pointed out in Section 8 .

As discussed above, the most outstanding feature of the Baiu over and around the Japan Islands is that many scales of motions (planetary-, large (synoptic)-, meso- $\alpha$-, meso- $\beta$ - and meso- $\gamma$-scale motions) are interacting with each other.

This multi-scale aspect of Baiu will be summarized in Fig. 35 as the important conclusion of the present review paper.

The panel A illustrates the planetary scale features in the Baiu season. The formation of the 


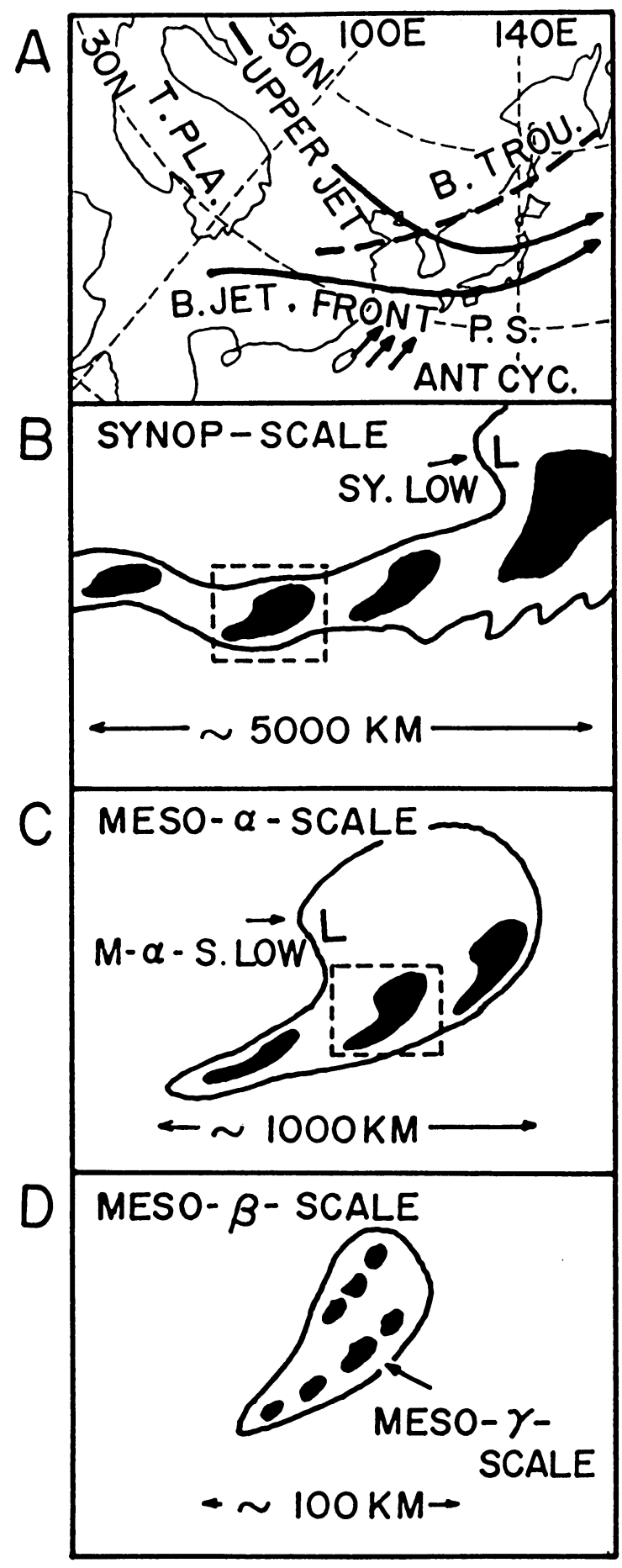

Fig. 35. Schematic illustration of the multiscale structure of the Baiu. Panel A: Planetary-scale circulation systems related to the Baiu front. Panel B: Large-scale features of the Baiu front in the form of a meso- $\alpha$-scale cyclone family. Panel C: A meso- $\alpha$-scale convective system in the Baiu front. Panel D: A meso- $\beta$-scale convective system in the meso- $\alpha$-scale Baiu frontal convective system. The meso- $\gamma$-scale fine structure is seen. (Adopted from Akiyama, 1983 and 1990a).
Baiu front with the Baiu low-level jet stream along the northwestern periphery of the Pacific subtropical anticyclone is the basic feature of the Baiu. The frontogenesis and the generation of convective instability due to the SW-WSW-ly winds along the Pacific anticyclone are the important factors to form and sustain the Baiu front. There is the upper jet stream over the polar frontal zone extending from the north of the Tibetan Plateau. There is the Baiu trough, as shown on the map, and the polar frontal zone shifts southward around $130^{\circ} \mathrm{E}$ to approach the Baiu frontal zone. Therefore, the structure of the Baiu front between $135-160^{\circ} \mathrm{E}$ is different from that between $100-125^{\circ} \mathrm{E}$.

While the synoptic-scale disturbances of a deep structure prevail in the polar frontal zone, the meso$\alpha$-scale frontal disturbances of shallow structure develop frequently in the Baiu frontal zone. The organized Baiu frontal cloud system of $\sim 5000 \mathrm{~km}$ length, that is, the "Baiu frontal meso- $\alpha$-scale cyclone family", forms under the influence of the polar frontal disturbance as schematically illustrated in the panel $\mathrm{B}$ of Fig. 35. The Baiu frontal cloud zone consists of a few meso- $\alpha$-scale Baiu frontal disturbances.

The panel C of Fig. 35 illustrates the fine structure of a meso- $\alpha$-scale Baiu frontal disturbance. While the continuous precipitation covers the northeastern part of the disturbance, a few meso- $\beta$-scale convective systems develop in the southern part of the meso- $\alpha$-scale disturbance.

As shown in the panel D of Fig. 35, the meso- $\beta$ scale convective system is further decomposed into a few meso- $\gamma$-scale convections.

We hope that more comprehensive and detailed studies on the multi-scale features of the Baiu phenomena will be made in the near future.

\section{References}

Akiyama, T., 1973a: Ageostrophic low-level jet stream in the Baiu season associated with heavy rainfalls over the sea area. J. Meteor. Soc. Japan, 51, 205208.

Akiyama, T., 1973b: The large-scale aspects of the characteristics of the Baiu front. Pap. Meteor. Geophys., 24, 157-188.

Akiyama, T., 1973c: Frequent occurrence of heavy rainfall along the north side to the low-level jet stream in the Baiu season. Pap. Meteor. Geophys., 24, 379388.

Akiyama, T., 1975: Southerly transversal moisture flux into the extremely heavy rainfall zone in the Baiu season. J. Meteor. Soc. Japan, 53, 304-316.

Akiyama, T., 1978: Mesoscale pulsation of convective rain in medium-scale disturbances developed in the Baiu front. J. Meteor. Soc. Japan, 56, 267-283.

Akiyama, T., 1979: Variation of thermal stratification in subtropical medium-scale disturbances. J. Meteor. Soc. Japan, 57, 587-598. 
Akiyama, T., 1983: An observational study of structure and maintenance of the Baiu front. Ph. D. diss. Tokyo University.

Akiyama, T.,1984a: A medium-scale cloud cluster in a Baiu front. Part I: Evolution process and fine structure. J. Meteor. Soc. Japan, 62, 485-504.

Akiyama, T., 1984b: A medium-scale cloud cluster in a Baiu front. Part II: Thermal and kinematic fields and heat budget. J. Meteor. Soc. Japan, 62, 505521.

Akiyama, T., 1989: Large, synoptic and meso scale variations of the Baiu front during July 1982. Part I: Cloud features. J. Meteor. Soc. Japan, 67, 57-81.

Akiyama, T., 1990a: Large, synoptic and meso scale variations of the Baiu front during July 1982. Part II: Frontal structure and disturbances. J. Meteor. Soc. Japan, 68, 557-574.

Akiyama, T., 1990b: Large, synoptic and meso scale variations of the Baiu front during July 1982. Part III: Space-time scale and structure of frontal disturbances. J. Meteor. Soc. Japan, 68, 705-727.

Asakura, T., 1971: Transport and source of water vapor in the Northern Hemisphere and monsoon Asia. Water balance at monsoon Asia, 27-51. University Tokyu Press.

Chen, S.-J. and L. Dell'Osso, 1984: Numerical predition of the heavy rainfall vortex over Eastern Asia monsoon region. J. Meteor. Soc. Japan, 62, 730-747.

Chen, T.-J.G. and Chang, C.-P., 1980: The structure and vorticity budget of an early summer monsoon trough (Mei-yu) over south-eastern China and Japan. Mon. Wea. Rev., 108, 942-953.

Flohn, H. and H. Oeckel, 1956: Water vapor flux during the summer rains over Japan and Korea. Geophys. Mag., 27, 527-532.

Kato, K., 1985: On the abrupt change in the structure of the Baiu front over China continent in late May of 1979. J. Meteor. Soc. Japan, 63, 20-36.

Kato, K., 1989: Seasonal transition of the lower level circulation systems around the Baiu front in China in 1979 and its relation to the northern summer monsoon. J. Meteor. Soc. Japan, 67, 249-265.

Kuo, Y.-H., L. Cheng and R.A. Anthes, 1986: Mesoscale analyses of the Sichuan flood catastrophe, 11-15 July 1981. Mon. Wea. Rev., 114, 1984-2003.

Kurashima, A., 1968: Studies on the winter and summer monsoon in East Asia based on dynamic concept. Geophys. Mag., 34, 145-235.

Lau, K.-M. and M.-T. Li, 1984: The monsoon of east Asia and its global associatiion. Bull. Amer. Meteor. Soc., 65, 114-125.

Luo, H. and M. Yanai, 1983: The large-scale circulation and heat sources over the Tibetan Plateau and surrounding areas during the early summer of 1979 . Part I: Precipitation and kinematic analyses. Mon. Wea. Rev., 111, 922-944.

Ma, K.-Y. and L.F. Bosart, 1987: A synoptic overview of a heavy rain event in Southern China. Weather Forecast, 2, 89-112.

Maddox, R.A., 1980: Mesoscale convective complexes. Bull. Amer. Meteor. Soc., 61, 1374-1387.

Matsumoto, S., 1972: Unbalanced low-level jet and solenoidal circulation associated with heavy rainfalls.
J. Meteor. Soc. Japan, 50, 194-203.

Matsumoto, S., 1973: Lower tropospheric wind speed and precipitation activity. J. Meteor. Soc. Japan, 51, 101-107.

Matsumoto, S. and T. Akiyama, 1969: Some characteristic features of the heavy rainfalls observed over western Japan on July 1967. Part I: Mesoscale structure and short period pulsation. J. Meteor. Soc. Japan, 47, 255-266.

Matsumoto, S. and T. Akiyama, 1970: Mesoscale disturbances and related rainfall cells embedded in the Baiu front with a proposal on the role of convective momentum transfer. J. Meteor. Soc. Japan, 48, 91102.

Matsumoto, S. and K. Ninomiya, 1971: On the mesoscale and medium-scale structure of a cold front and the relevant vertical circulation. J. Meteor. Soc. Japan, 49, 648-662.

Matsumoto, S., K. Ninomiya and S. Yoshizumi, 1971: Characteristic features of Baiu front associated with heavy rainfall. J. Meteor. Soc. Japan, 49, 267-281.

Matsumoto, S., S. Yoshizumi and M. Takeuchi, 1970: On the structure of the Baiu front and the associated intermediate-scale disturbances in the lower atmosphere. J. Meteor. Soc. Japan, 48, 479-491.

Myrakami, T., 1958: The sudden change of upper westerlies near the Tibetan Plateau at the beginning of summer season. J. Meteor. Soc. Japan, 36, 239-247.

Murakami, T., 1959: The general circulation and water vapor balance over the Far East during the rainy season. Geophys. Mag., 29, 131-171.

Murakami, T. and W.-G. Huang, 1984: Orographic effects of the Tibetan Plateau on the rainfall variations over central China during the 1979 summer. J. Meteor. Soc. Japan, 62, 895-909.

Nakamura, H. and N. Hasegawa, 1987: Forecast experiments on the large-scale feature of the Baiu front. Short- and Medium-range Numerical Weather Prediction. Special Volume of J. Meteor. Soc. Japan, 441-453.

Ninomiya, K., 1968: Heat and water budget over the Japan Sea and the Japan Islands in winter season. J. Meteor. Soc. Japan, 46, 343-372.

Ninomiya, K., 1976: Wind profile and kinetic energy budget in the mixed layer of polar airmass transformed over Kuroshio region. J. Meteor. Soc. Japan, 54, 361-369.

Ninomiya, K., 1978: Heavy rainfalls associated with frontal depression in Asian subtropical humid region. Part I: Synoptic features. J. Meteor. Soc. Japan, 56, 253-266.

Ninomiya, K.,1980: Enhancement of Asian subtropical front due to thermodynamic effect of cumulus convections. J. Meteor. Soc. Japan, 58, 1-15.

Ninomiya, K., 1984: Characteristics of Baiu front as a predominant subtropical front in the summer northern hemisphere. J. Meteor. Soc. Japan, 62, 880-894.

Ninomiya, K., 1989: Cloud distribution over East Asia during Baiu period of 1979. J. Meteor. Soc. Japan, 67, 639-658.

Ninomiya, K. and T. Akiyama, 1971: The development of the medium-scale disturbance in the Baiu front. J. Meteor. Soc. Japan, 49, 663-677. 
Ninomiya, K. and T. Akiyama, 1972: Medium-scale echo cluster in the Baiu front as revealed by multi-radar composite echo map. Part I: J. Meteor. Soc. Japan, 50, 558-569.

Ninomiya, K. and T. Akiyama, 1973: Medium-scale echo cluster in the Baiu front as revealed by multi-radar composite echo map. Part II, J. Meteor. Soc. Japan, 51, 108-118.

Ninomiya, K. and T. Akiyama, 1974: Band structure of mesoscale echo cluster associated with low-level jet stream. J. Meteor. Soc. Japan, 52, 300-313.

Ninomiya, K. and T. Akiyama, 1976: Structure and heat energy budget of mixed layer capped by inversion during the period of polar air outbreak over Kuroshio region. J. Meteor. Soc. Japan, 54, 160-174.

Ninomiya, K. and H. Mizuno, 1987: Variations of Baiu precipitation over Japan in 1951-1980 and large-scale characteristics of wet and dry Baiu. J. Meteor. Soc. Japan, 65, 115-127.

Ninomiya, K. and T. Murakami, 1987: The early summer rainy season (Baiu) over Japan. Monsoon $\mathrm{Me}$ teorology, 93-121. Oxford University Press.

Ninomiya, K. and H. Muraki, 1986: Large-scale circulations over the East Asia during Baiu period of 1979. J. Meteor. Soc. Japan, 64, 409-429.

Ninomiya, K. and Y. Tatsumi, 1980: Front with heavy rainfalls in the Asian subtropical humid region in a 6 -level $77 \mathrm{~km}$-mesh primitive equation model. J. Meteor. Soc. Japan, 58, 172-186.

Ninomiya, K. and Y. Tatsumi, 1981: Forecast experiment of Long-Lived subtropical cumulonibus cluster with 6 -level $77 \mathrm{~km}$-mesh primitive model. J. Meteor. Soc. Japan, 59, 709-722.

Ninomiya, K. and K. Yamazaki, 1979: Heavy rainfall associated with frontal depression in Asian subtropical humid region. Part II: Mesoscale features of precipitation, radar echoes and stratification. J. Meteor. Soc. Japan, 57, 399-413.

Ninomiya, K., T. Akiyama and M. Ikawa, 1988a: Evolution and fine structur of a long-lived meso- $\alpha$-scale convective system in Baiu frontal zone. Part I: Evolution and meso- $\beta$-scale characteristics. J. Meteor. Soc. Japan, 66, 331-350.

Ninomiya, K., T. Akiyama and M. Ikawa, 1988b: Evo- lution and fine structure of a long-lived meso- $\alpha$-scale convective system in Baiu frontal zone. Part II: Meso- $\gamma$-scale characteristics of precipitation. J. Meteor. Soc. Japan, 66, 351-371.

Ninomiya, K., M. Ikawa and T. Akiyama, 1981: Longlived medium-scale cumulonimbus cluster in Asian subtropical humid region. J. Meteor. Soc. Japan, $\mathbf{5 9}, 564-577$.

Ninomiya, K., H. Koga, Y. Yamagishi and Y. Tatsumi, 1984: Prediction experiment of extremely intense rainstorm by a very fine-mesh primitive equation model. J. Meteor. Soc. Japan, 62, 273-295.

Orlanski, I., 1975: A rational subdivision of scales for atmospheric processes. Bull. Amer. Meteor. Soc., 56, $527-530$.

Saito, N., 1966: A preliminary study of the summer monsoon of southern and eastern Asia. J. Meteor. Soc. Japan, 44, 49-59.

Saito, N., 1985: Quasi-stationary waves in mid-latitudes and the Baiu in Japan. J. Meteor. Soc. Japan, 63, 983-995.

Tao, S. and L. Chen, 1986: A review of recent search on the East Asian summer monsoon in China. Monsoon Meteorology, 60-92. Oxford University Press.

Tao, S.-Y. and Y.-H. Ding, 1981: Observational evidence of the influence of the Quinghai-Xizang Plateau on the occurrence of heavy rain and severe convective storms in China. Bull. Amer. Meteor. Soc., 62, 2330 .

Tokioka, T., 1970: Non-geostrophic and non-hydrostatic stability of a baroclinic fluid. J. Meteor. Soc. Japan, 48, 503-520.

Tokioka, T., 1973: A stability study of medium-scale disturbances with inclusion of convective effects. $J$. Meteor. Soc. Japan, 51, 1-10.

Yoshino, M., 1965: Four stages of the rain season in early summer over East Asia. Part I: J. Meteor. Soc. Japan, 43, 231-245.

Yoshino, M., 1966: Four stages of the rain season in early summer over East Asia. Part II. J. Meteor. Soc. Japan, 44, 209-217.

Yoshizumi, S., 1977: On the structure of intermediatescale disturbances on the Baiu front. J. Meteor. Soc. Japan, 55, 107-120.

\title{
梅雨の多種スケール階層構造
}

\author{
二宮洸三 \\ (気象庁海洋気象部) \\ 秋山孝子 \\ (気象研究所)
}

梅雨に関する著者の一連の研究を review し、その多種スケール階層構造を強調した。

東アジアの夏季モンスーン雨期の特徴の一つは、チベット高原南東から東に伸びる長大な準定常的な降 水ゾーン（梅雨前線）の形成である。梅雨前線は熱帯気団の北縁にそって形成され、対流圈下層の $\nabla \theta e$ 極 
大ゾーンとして認められる。その西部分 $\left(100 \sim 130^{\circ} \mathrm{E}\right)$ では $\nabla \theta$ は弱く、大きな $\nabla q$ によって特徴づけられ、

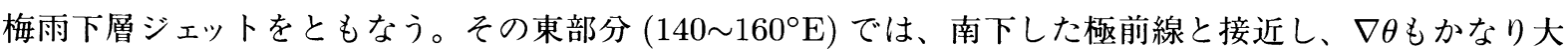
きい。

梅雨前線に関する大規模循環系としては、中高緯度の極前線とそれにともなう上層ジェットおよび梅雨 トラフ、低緯度では、インドモンスーン風系と太平洋亚熱帯高気圧が重要である。特に太平洋亜熱帯高気 圧の西〜北西縁の強い南西〜西南西流による変形場における frontogenesis 、 differential advection による 対流不安定生成が注目される。このように梅雨前線は夏季北半球における特徴ある準定常的亜熱带前線と して位置づけられる。これに類似した前線系は、夏季北半球の他領域には見出されない。

梅雨前線にそっては meso- $\alpha$-scale 低気圧がしばしば発生し、強い対流性降水をもたらす。梅雨最盛期の 梅雨前線と非地衡風的梅雨下層ジェトの構造を示した。水蒸気収支については下層南西流による水蒸気 流束収束の重要性が示された。

梅雨前線豪雨の典型例について、下層ジェット軸のまわりの鉛直循環を示し、対流不安定の分布、differential advection による対流不安定の生成を評価し、また $\theta e$ 収支解析によって、対流による対流不安定の解消を 論じた。

梅雨前線の meso- $\alpha$-scale 低気圧（渦度分布図上、 $\zeta_{\max }$ として検出される）の多くは meso- $\alpha$-scale の雲 システム (cloud cluster) をともなう。極前線低気圧が南下する場合には梅雨前線の低気圧と複雑に影響 し合う。この様な場合、極前線低気圧を先頭とし、その西南西に連なる梅雨前線帯の meso- $\alpha$-scale 低気圧 family が発達し、前線活動が活発になる。

梅雨期の擾乱の統計的特徵を調べるため、雲量、渦度、比湿の spectral 解析を行った。極前線帯では傾 圧波の構造を持つ総観規模低気圧が卓越する。梅雨前線帯では周期 $2 \sim 3$ 日の meso- $\alpha$-scale 擾乱が卓越す る。位相の解析から、その鉛直軸は対流圈下層では東傾し、比湿極大軸の上空に負渦度を持つ構造が示さ れた。チベット高原南東部では日変化が非常に強い。

静止衛星データー、レーダーデーターによって meso- $\alpha$-scale 低気圧の微細構造としての meso- $\beta$-および meso- $\gamma$-scale 降水システムを指摘した。

このように梅雨は planetary scale から meso scale におよぶ多種スケールの相互作用のもとにあらわれる 多種スケール階層構造をもつ現象として理解すべきことを強調した。 